\title{
Tensile strength of large-scale incipient rock joints: a laboratory investigation
}

\author{
J. Shang ${ }^{1,2}$ (1) L. J. West ${ }^{1} \cdot$ S. R. Hencher ${ }^{1,3,4} \cdot$ Z. Zhao $^{2}$
}

Received: 16 April 2017 / Accepted: 11 December 2017 / Published online: 18 December 2017

(C) The Author(s) 2017. This article is an open access publication

\begin{abstract}
In this paper, a testing methodology was developed in the laboratory to measure the tensile strength of large-scale incipient rock joints. In the test, an expansive grout was used to develop the tensile force. Each test comprises two phases: Phase i test and Phase ii test. The Phase i test identified sample failure time, while the Phase ii test measured the corresponding tensile force arising from the expansive grout. Ostensibly homogeneous rock samples without incipient joints were firstly tested to establish the methodology. Tensile strength of block samples containing incipient rock joints was then measured using the established testing scheme. The test results have been compared with those obtained from conventional Brazilian and uniaxial tension tests as suggested by ISRM. The proposed approach is capable of giving a measure of tensile strength of large-scale incipient rock joints, although somewhat smaller strength than that from the standard approaches was occasionally measured in the preliminary tests on ostensibly homogeneous samples. Effects of stress concentration, sample scale, loading rate and expansive tensile force on the testing results were discussed. Furthermore, this simple and practical testing scheme is proposed for the measurement of the in situ tensile strength of rock and incipient discontinuities in the field, which if successful will provide a more scientific guidance on the rock mass classification and engineering design.
\end{abstract}

Keywords Expansive grout $\cdot$ Incipient rock joints $\cdot$ Large-scale test $\cdot$ Rock bridges $\cdot$ Rock mass $\cdot$ Tensile strength

\section{List of symbols}

$F_{D(t)}$

Expanding force $(\mathrm{kN})$ from expansive grout which varies with time, grout concentration grout amount and room temperature

$F_{r} \quad$ Resisting force $(\mathrm{kN})$ of intact rock material/ incipient joint to be tested

$F_{i} \quad$ Resisting force $(\mathrm{kN})$ of rock material/ incipient joint at the point of fracture initiation

J. Shang

shangjunlongcsu@gmail.com

$\triangle$ L. J. West

L.J.West@leeds.ac.uk

1 Engineering Geology and Hydrogeology Group, School of Earth and Environment, University of Leeds, Leeds, UK

2 School of Civil and Environmental Engineering, Nanyang Technological University, Singapore, Singapore

3 Department of Earth Sciences, University of Hong Kong, Pokfulam, Hong Kong, SAR, China

4 Hencher Associates Limited, Ilkley, UK
$F_{m} \quad$ Maximum resisting force $(\mathrm{kN})$ of rock material/incipient joint at sample failure, i.e. the tensile strength of the large-scale rock material or incipient joint (expressed in force units)

$F_{\mathrm{LC}} \quad$ Measured force $(\mathrm{kN})$ using load cell

$F_{\mathrm{LCA}}$ and Measured force $(\mathrm{kN})$ using load cell $\mathrm{A}$ and $F_{\mathrm{LCB}} \quad$ load cell B, respectively

$F_{\mathrm{PR}} \quad$ Measured force $(\mathrm{kN})$ using proving ring $\operatorname{ETF}_{(t)} \quad$ The total expansive tensile force $(\mathrm{kN})$ perpendicular to the splitting plane from expansive grout

\section{Introduction}

Rock discontinuities including joints, faults, cleavage and bedding planes control the mechanical and hydrogeological properties of fractured rock masses [1, 3, 24, 27, 34, 42]. Incipient rock joints can have considerable tensile strength arising from residual rock bridges (due to partial development) or from secondary mineralization [13, 32]. They will ultimately develop into mechanical fractures with zero 
tensile strength (following the definition of ISRM [17]), in response to temperature and insolation [5], precipitation [39], weathering [4, 11-13], seismic loading [7] and mechanical breakage. Figure 1a shows a piece of finegrained sandstone core containing many incipient rock joint traces that were not fully developed, due to the presence of rock bridges having considerable tensile strength. On the same core, several mechanical joints following the previous incipient traces were generated after impact of a geological hammer (Fig. 1b), and it can be imaging that the smaller block pieces were readily to be removed as there is zero true cohesion. It is clear that the joints shown in Fig. 1a, b need to be differentiated in terms of strength in rock mass classification and characterization in practical rock engineering.

Rock bridges, small intact/strong rock materials separating coplanar and non-coplanar discontinuities, significantly increase the tensile strength of rock discontinuities as they produce a strength reserve that is mobilized prior to failure $[8,9,19,29,36]$. Hencher [13] tested a rock bridge with a true cohesion of $750 \mathrm{kPa}$ by shearing a core sample in the laboratory. At a larger scale, a rock bridge having a size of about $150 \mathrm{~mm} \times 300 \mathrm{~mm}$ was reported by Paolo et al. [29] after collapse of a limestone wedge in the field; cohesion of the bridge was back calculated to be around 2.3 MPa. Nevertheless, tensile strength of rock discontinuities has been largely ignored as it is widely assumed that rock joints have very low or zero tensile strength; in fact, this assumption only applies to mechanical fractures. In the field or underground mines, there have been many
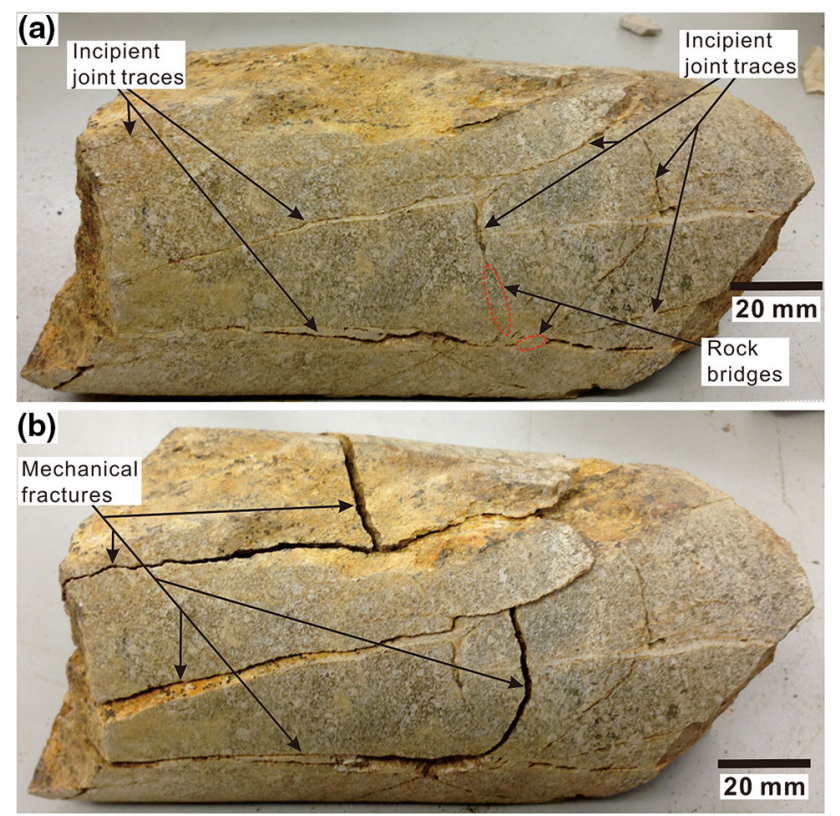

Fig. 1 Section of a Midgley Grit Sandstone core with incipient joints and rock bridges (a) and mechanical fractures on the same core created by the impact of a geological hammer (b) overhanging rock blocks on steep cliffs or cavity roofs that are soundly connected to host rock only because of the presence of rock bridges [20,29]. These blocks tend to fail by tension in response to weathering, precipitation or mining activities. It is, however, quite difficult to assess their stability. Laboratory-scale tests on natural rock samples containing incipient rock discontinuities have been conducted by Shang et al. [32], aiming to measure the tensile strength of incipient rock discontinuities and differentiate incipient traces using relative tensile strength. It was demonstrated that incipient discontinuities including joints, bedding planes and mineral veins can have high tensile strength, some of them even approaching that of parent rock.

Scale effects have been found on uniaxial compressive strength [30] and shear strength [2] of rock and rock joints. The aim of this paper is not to investigate the scale effect but to develop a practical methodology to measure the tensile strength of large-scale incipient rock joints. A conceptual test approach has been developed in the laboratory, in which an expansive grout was used to develop the tensile force. Preliminary verification tests were firstly conducted using block-scale intact rock samples following by tests on incipient rock joints. This approach is proposed for use in the field to assess the tensile strength of largescale incipient rock discontinuities.

\section{Experimental apparatus and preparation}

A set of 36-V cordless drill (Model: Makita) with three operation modes (rotation, hammering and rotation plus hammering) was used to drill holes in rock matrix as well as along incipient rock joint planes. The drill has a vibration-absorbing handle, a soft grip and drill bits with varying diameters up to $26 \mathrm{~mm}$ to drill in rock or concrete materials. Four 18-V-2.6Ah Li-ion batteries BL3626 and two $36-\mathrm{V}$ battery chargers were employed so that the drill can work continuously for a test run.

A 50-kN proving ring (PR) with a LVDT was used in the laboratory tests to log the sample failure point. A servocontrolled uniaxial testing machine (MAND) with a capacity of $250 \mathrm{kN}$ was used to calibrate the PR, as shown in Fig. 2. A tensile loading rate of $33 \mathrm{~N} / \mathrm{s}$ was adopted to apply tensile force gradually. Figure 3 shows the relationship of tensile force to displacement of the PR. The stiffness constant of the $50 \mathrm{kN}$ PR used in the tests is 0.06 $(\mathrm{mm} / \mathrm{kN})$ with a $R^{2}$ of 0.999 , and it demonstrates that the PR used in the study works well as there is no initial resistance force.

In the test, an expansive grout was used to apply pressure to the sample instead of a traditional servo-controlled loading machine. The expansive grout is a mixture of 


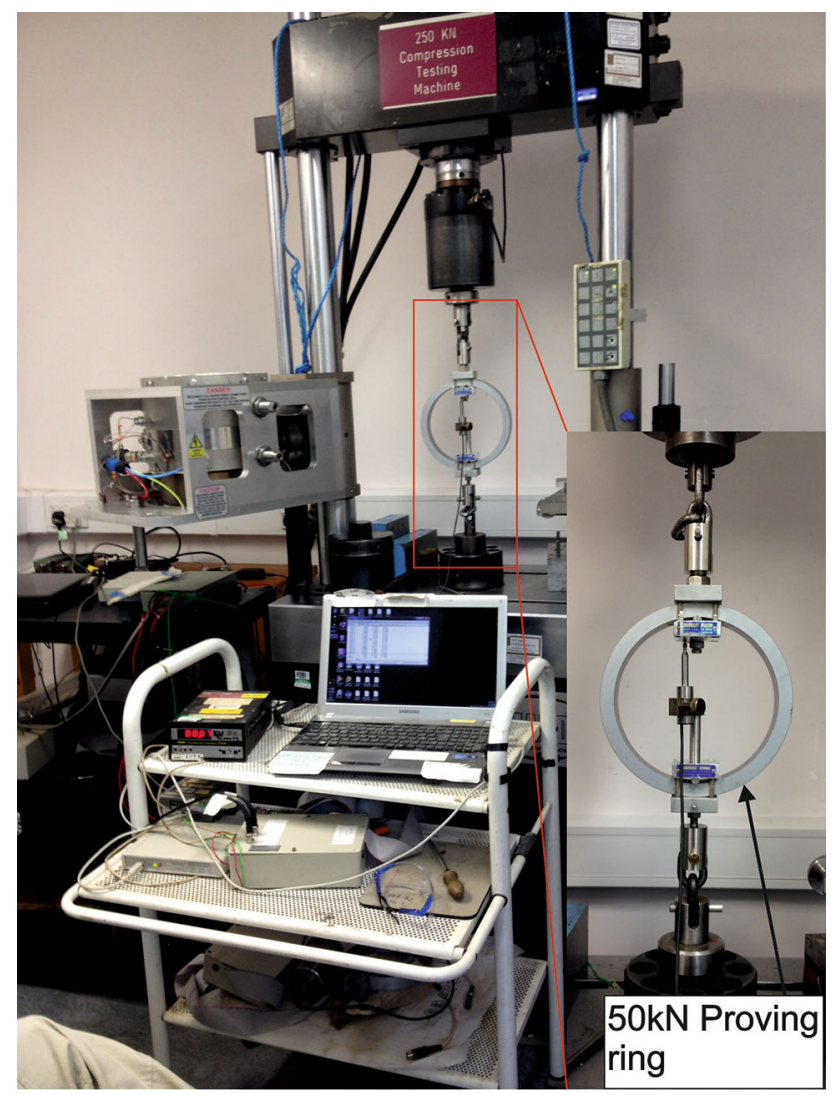

Fig. 2 Setup and calibration of a 50-kN proving ring using a universal testing machine

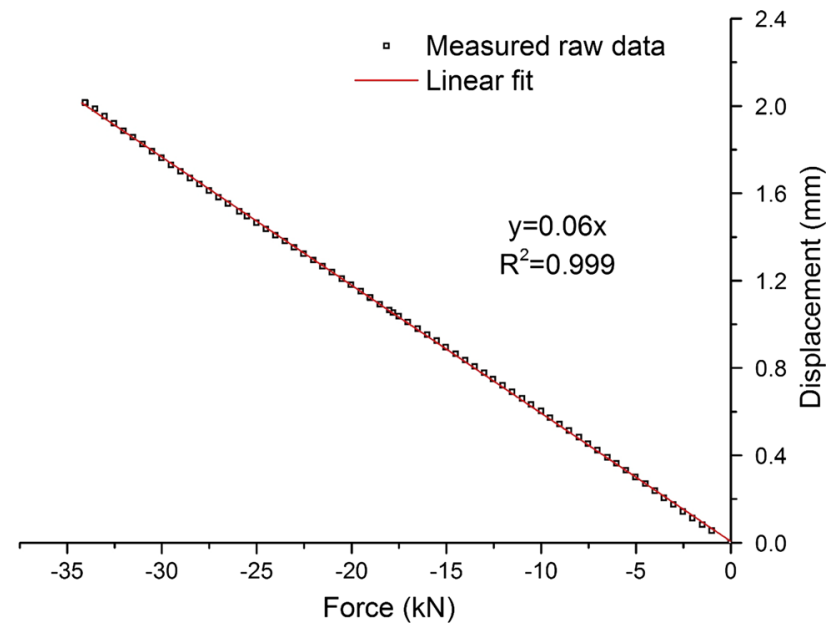

Fig. 3 Relationship between force and displacement of the proving ring calibrated in Fig. 2

Dexpan power (non-toxic material generally comprising $\mathrm{SiO}_{2}, \mathrm{Al}_{2} \mathrm{O}_{3}, \mathrm{Fe}_{2} \mathrm{O}_{3}, \mathrm{CaO}, \mathrm{MgO}$ and $\mathrm{SO}_{3}$ [16]) and water with a recommended ratio of $3.3 \mathrm{~kg} / \mathrm{L}$. Dexpan is a commercial product used to crack rocks and concrete in engineering projects where no vibrations or blasting are allowed. According to the manufacturer, the expansive strength can reach 18,000 psi (around $124 \mathrm{MPa}$ ) arising from the chemical reaction when mixed with water. The strength capacity, however, depends on some factors including grout concentration, working/rock temperature and the amount of grout used. Three different types of Dexpan are available (type 1 from -5 to $10^{\circ} \mathrm{C}$, type 2 from 10 to $25^{\circ} \mathrm{C}$ and type 3 from 25 to $40{ }^{\circ} \mathrm{C}$ ). In this study, type 2 Dexpan was used in the laboratory experiment. Generally, it takes approximately $24 \mathrm{~h}$ for Dexpan to generate its full force and the rock or concrete will break within that period depending on strength. In the experiment, chemical splitter (in this paper the term chemical splitter is used interchangeably with expansive grout) was injected into two symmetrical holes drilled within intact block samples or along incipient joint traces to generate expansive tensile force (ETF) (normal to splitting plane). Figure 4 shows a schematic diagram of the relation of the expanding force $\left(F_{D(t)}\right)$ and ETF.

Three button-compression load cells and compatible instrumentation were used in the experiments to measure the force generated from the chemical splitter. One is a readily available load cell with a small button and a capacity of $50 \mathrm{kN}$; two other large button-style load cells with the same capacity were specially manufactured by Nova tech Measurements Ltd to a size which is suitable for the tests. A linear variable differential transformer (LVDT) with a high accuracy of $\pm 0.1 \%$ and a capacity of $0-5 \mathrm{~mm}$ was used with the PR for the accurate measurement of the displacement of the PR under tension. In addition, two 600-mm heavy-duty adjustable clamps, manufactured metal connectors suitable for the PR, 15-mm threaded rods and nuts were used to install the load cells and the PR in the test configuration. Grey spectrum plasticine (a soft and pliable modelling material) was used to seal open edges and bottoms of holes to prevent expansive grout from leaking. Wooden supports and a base board were also used in the tests.

\section{Experimental methodology and setup}

\subsection{Experimental scheme and conceptual model}

The conceptual test model of the proposed methodology is shown in Fig. 5. Each test comprises two phases: Phase i test and Phase ii test. The Phase i test reports the actual test on the sample, i.e. either intact rock or an incipient discontinuity. The Phase ii test is conducted on the broken sample to measure the ETF generated by the chemical splitter. Two parameters including the failure time of sample under tension (measured in the Phase $i$ test) and the corresponding $\mathrm{ETF}_{(t)}$ (measured in the Phase ii test) at this time are measured. It is assumed that the ETF measured in 
(a)

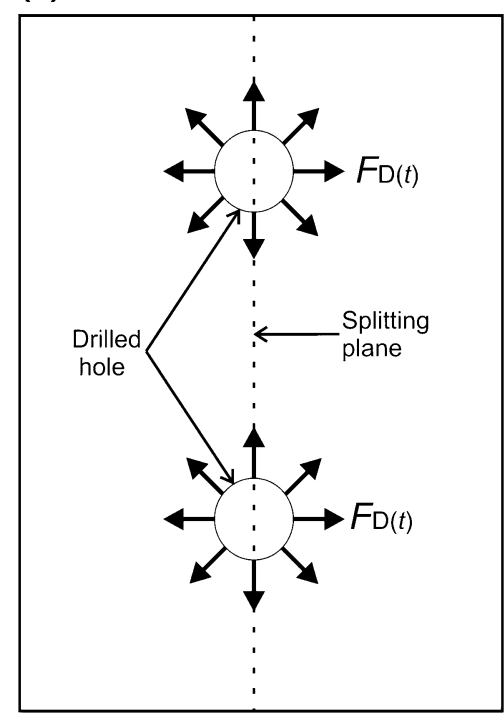

Expanding force $\left(F_{\mathrm{D}(t)}\right)$ from chemical splitter (b)

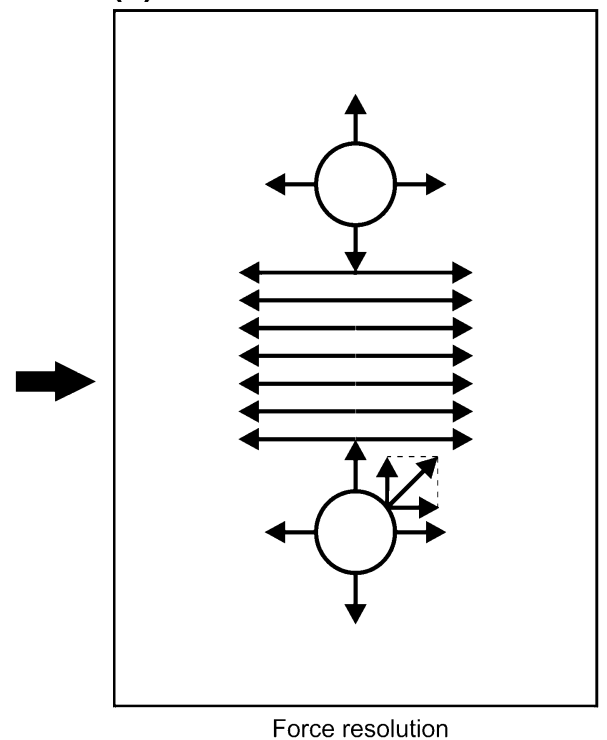

(c)

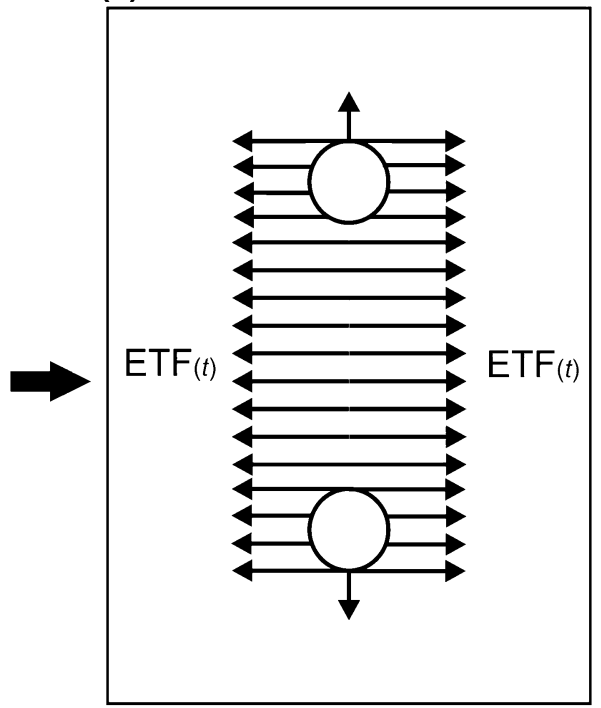

$\operatorname{ETF}(t)$ from chemical splitter

Fig. 4 Schematic diagram showing the expanding force from the chemical splitter and expansive tensile force (ETF) perpendicular to the splitting plane

the Phase ii test represents the ETF at the same time in the Phase i test.

Schematic experimental graphs for each phase of test are also presented in Fig. 5. The Phase i test was conducted on an ostensibly homogeneous block sample with or without an incipient joint to find the time of sample failure $\left(t_{2}\right)$. A PR with a LVDT was installed at the top of the sample, and note that there was no constraint at the base. Chemical splitter was employed to apply tensile force parallel to the LVDT in the middle. The whole test is assumed to occur under a state of static equilibrium due to the slow chemical reaction of the splitter.

Figure 5a presents a simplified force diagram in the Phase $i$ test. At the initiation of the test ( $t_{0}$ in Fig. 5a), there will be no forces as chemical splitter takes time to generate force. After initiation of the Phase i test, chemical splitter expanded gradually to apply tensile force acting on the plane through the chemical splitter-filled holes. LVDT measured essentially zero displacement until at the time when sample failed. At the point when sample failed in the Phase i test, ETF equalled $F_{\mathrm{m}}$ (at $t_{2}$ in Fig. 5b). A fracture plane (shown in the second image in the Phase $\mathrm{i}$ test in Fig. 5) was induced along the plane through chemical splitter-filled holes. At this time, LDVT started to measure displacement (under decompression), as schematically shown in Fig. 5a. A gap was generated at the base of the sample once it failed, because of the unconfined condition at the bottom of the sample.

The broken sample containing an opened fracture was re-employed in the Phase ii test (see the right column in Fig. 5). Two load cells were installed in parallel, and the
Fig. 5 Schematic diagram of the conceptual test model comprised of Phase i test and Phase ii test. The Phase i test (left column) is conducted to $\log$ the failure time of intact rock sample with or without incipient joint, while the Phase ii test (right column) is performed to measure the ETF. Schematic diagrams of the displacement of LVDT versus time (a) (measured in the Phase i test) and force versus time (b) (measured in the Phase ii test) are also included

ETF generated by the chemical splitter was measured. Figure $5 \mathrm{~b}$ schematically shows the measured force versus time. The ETF at the time $t_{2}$ (sample failure time in the Phase $\mathrm{i}$ test) was identified at which time it was assumed the ETF was equal to the maximum resisting force of rock material $\left(F_{\mathrm{m}}\right)$. Figure 6a shows the progressive development of the ETF, which is opposed by $F_{\mathrm{r}}$ in the Phase $\mathrm{i}$ test when the sample failed at $t_{2}$. Figure $6 \mathrm{~b}$ presents the relationship between the forces measured by the load cells and ETF in the Phase ii test.

\subsection{Experimental setup}

In this section, detailed experimental setups on intact rock samples without incipient joints, samples containing a single incipient joint (Phase $\mathrm{i}$ test) and broken samples containing the induced fracture from the Phase i test (Phase ii test) are described.

Figure 7 shows the Phase $\mathrm{i}$ experimental setups on an intact block sample and a sample with a vertical incipient joint. As for the test on the intact sample (Fig. 7a), apart from the chemical splitter-filled holes, two additional holes with the same diameter as the threaded rods were drilled to install the PR, and nuts were used to make sure the rigid 


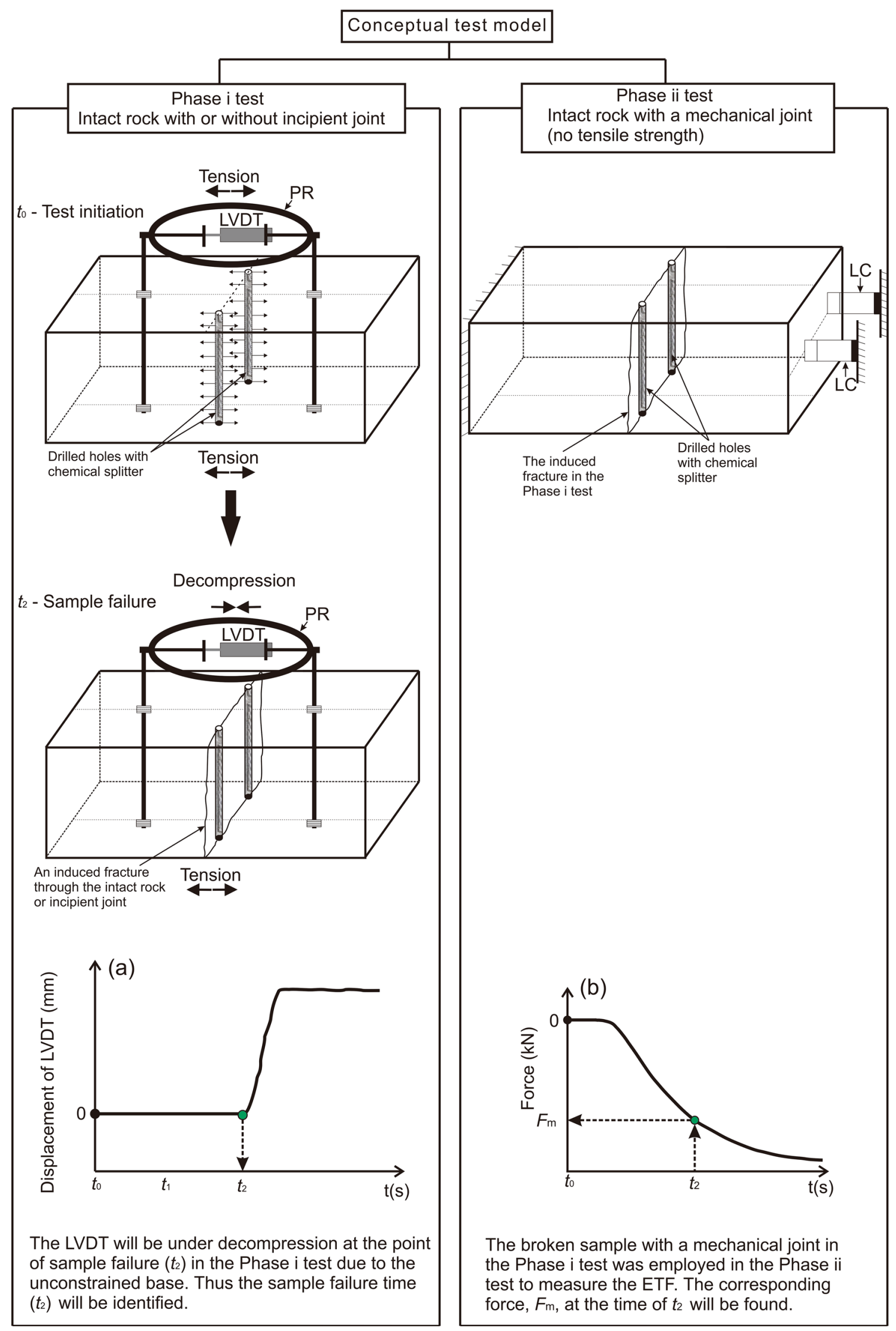


connection between the PR and the sample. A LVDT was employed to measure the displacement and hence identify the point of sample failure as stated in Sect. 3.1. For the tests on the samples containing an incipient joint (Fig. 7b), the setup procedure is similar to that described in Fig. 7a. The main difference is that two holes were drilled along the incipient joint plane (assuming that the joint surface is planar). Similarly, the failure point of the incipient joint under tension can be logged in the Phase i test.

Subsequently, the Phase ii test was conducted on the same samples tested in Fig. 7 but containing the fracture induced in the Phase $\mathrm{i}$ test to measure the ETF. Figure 8 shows two different Phase ii experimental setups on the rock samples containing mechanical joints. For the first setup (Fig. 8a), the PR (stiffness: $\mathrm{k}_{1}$ ) and load cell (stiffness: $k_{2}$ ) were installed parallel on the top and base of sample separately. $\operatorname{ETF}_{(t)}$ can be calculated by adding up two readings of the forces from the $\mathrm{PR}\left(F_{(\mathrm{PR})}\right)$ and load cell $\left(F_{(\mathrm{LC})}\right)$. In the second arrangement, in order to eliminate the potential influence of the stiffness difference between the PR and load cell in the measurement of $\operatorname{ETF}_{(t)}$, two load cells A and B with equal stiffness were employed in the test. The twin load cells were installed symmetrically, as shown in Fig. 8b. $\operatorname{ETF}_{(t)}$ was then obtained by adding up the two readings from the twin load cells (i.e. $F_{(\mathrm{LCA})}$ and $\left.F_{(\mathrm{LCB})}\right)$. Prior to testing, spectrum plasticine was used to seal the broken edges of holes and bottom of holes to prevent the chemical splitter from leaking.

\subsection{Tensile strength calculation}

Tensile strength of the plane through the chemical splitterfilled holes was calculated by dividing the $\operatorname{ETF}_{(t)}$ when sample failed by the area $(A)$ of the failure plane, which is expressed by the following equation:

$\sigma_{t}=\frac{\operatorname{ETF}_{(t)}}{A}$

where tensile stress $\left(\sigma_{t}\right)$ is represented as a negative quantity.
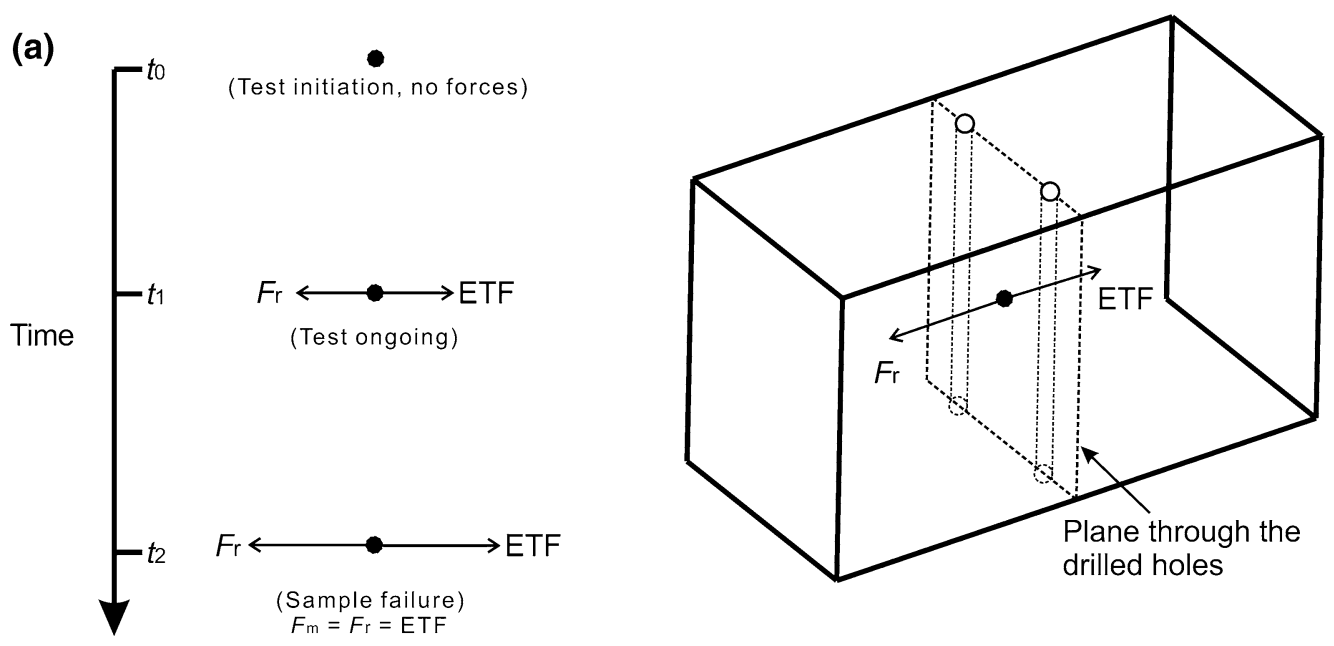

(b)

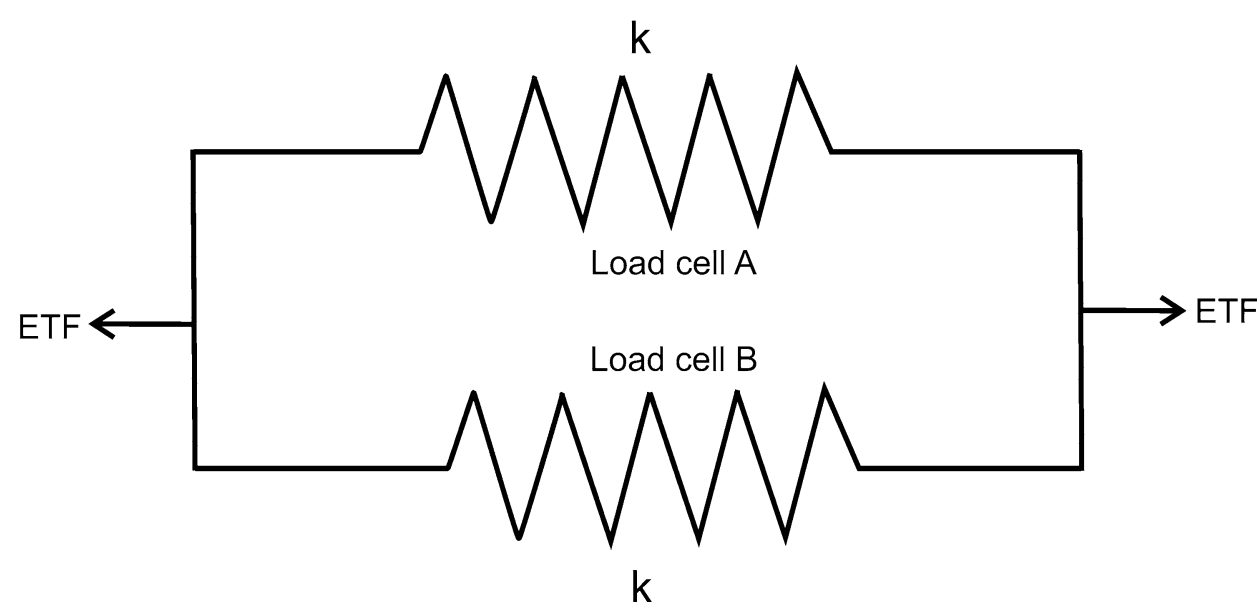

Fig. 6 a Force diagrams during different procedures in the Phase i test and $\mathbf{b}$ simplified force diagram for the Phase ii test 

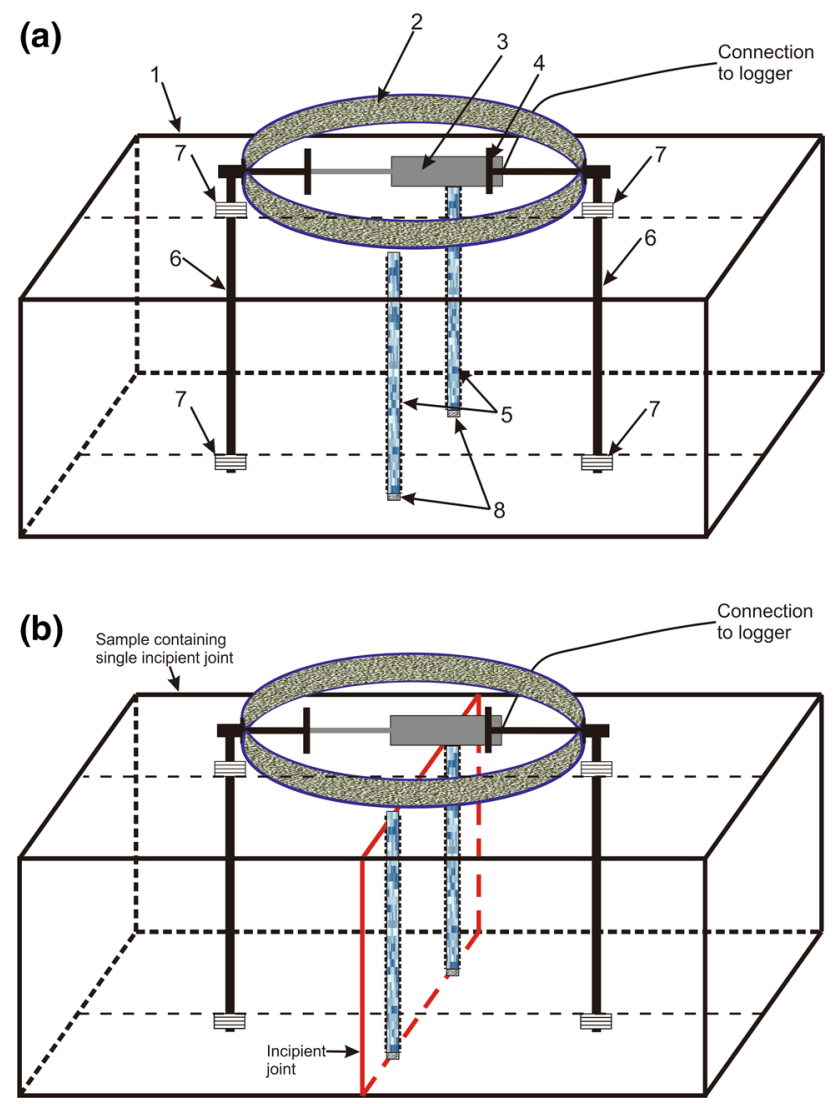

Fig. 7 Diagram of the test setups on intact rock blocks without (a) and with an incipient joint (b). 1-Intact rock sample without incipient joint; 2-a proving ring $(50 \mathrm{kN})$; 3-LVDT; 4-LVDT holder; 5-chemical splitter; 6-threaded rods; 7-nuts; 8-spectrum plasticine on the bottom. Figure not to scale

\section{Test model establishment}

Experimental schemes on ostensibly homogeneous rock samples and samples containing an incipient joint are the same. Tension tests on intact Thornhill Rock Sandstone and Midgley Grit Sandstone samples without incipient joints were firstly conducted to establish the procedure.

\subsection{Tensile tests on intact Thornhill Rock Sandstone}

Suitable samples of Thornhill Rock Sandstone with a pale greyish colour and uniform texture were collected from the Caulms Wood Quarry, West Yorkshire, UK. Sample ends were trimmed parallel and flat. The prepared sample (see Fig. 9a) with approximate dimensions of $150 \mathrm{~mm}$ (height) $\times 280 \mathrm{~mm}$ (length) $\times 170 \mathrm{~mm}$ (width) was used in the test. The block sample was stored in air dry condition in the laboratory. Some physical and mechanical properties including water content (3.8\%), Schmidt hammer (L-type)
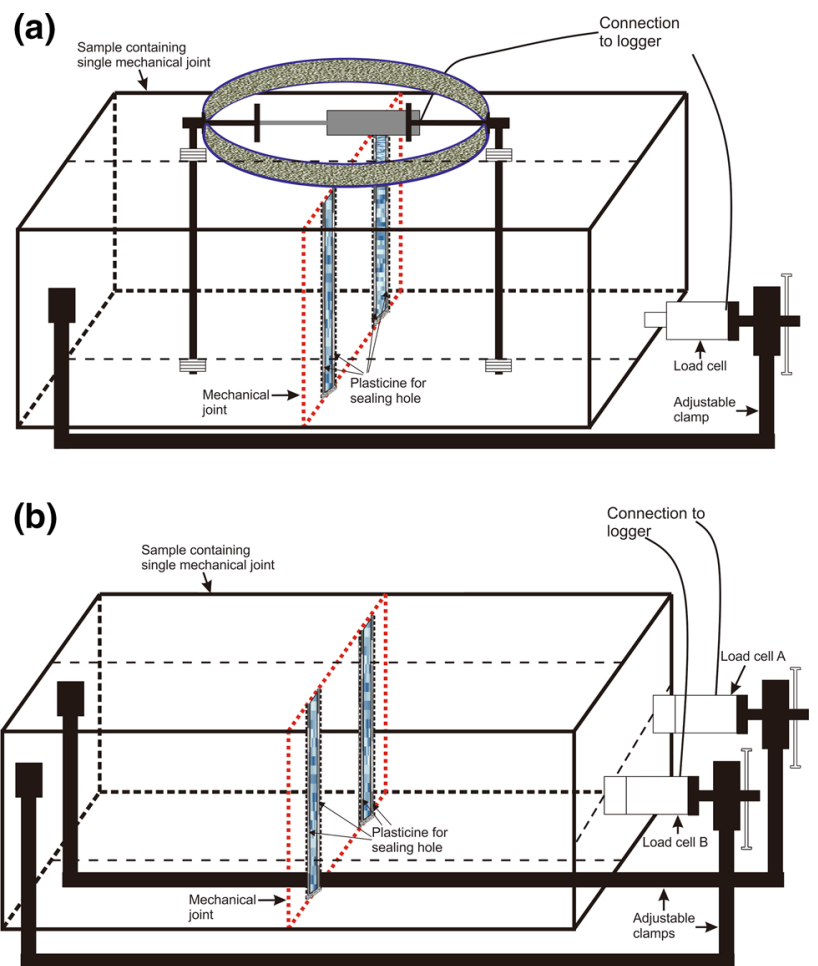

Fig. 8 Diagram of the test setups on intact rock blocks containing fractures opened in the Phase i test (to measure ETF). a The Type 1 re-setup method and $\mathbf{b}$ the Type 2 re-setup method. Figure not to scale

rebound hardness $(43 \pm 2)$, uniaxial compressive strength $(49 \pm 2.8 \mathrm{MPa})$ and point load strength $I_{\mathrm{s}(50)}$ $(1.9 \pm 0.1 \mathrm{MPa})$ were measured according to ISRM standards [18]. The procedures for measuring these properties were briefly summarized below.

\subsubsection{Water content}

Small irregular samples were weighed using an electronic precision balance, and a drying oven setting at around $105^{\circ} \mathrm{C}$ was used to dry samples for $24 \mathrm{~h}$. The weight difference of samples prior to and after drying was used to find the water content.

\subsubsection{Schmidt hammer rebound hardness}

An intact air-dried Thornhill Rock Sandstone sample with a thickness of $120 \mathrm{~mm}$ at the point of impact was used for the measurement of the Schmidt hammer rebound hardness [18]. In this test, the block was placed on the ground and was clamped by another two larger rock blocks to prevent the sample from sliding or moving during testing. A L-type hammer was impacted normal to the rock surface. Mean rebound value of 43 with a standard deviation of 2 was obtained in this test. 

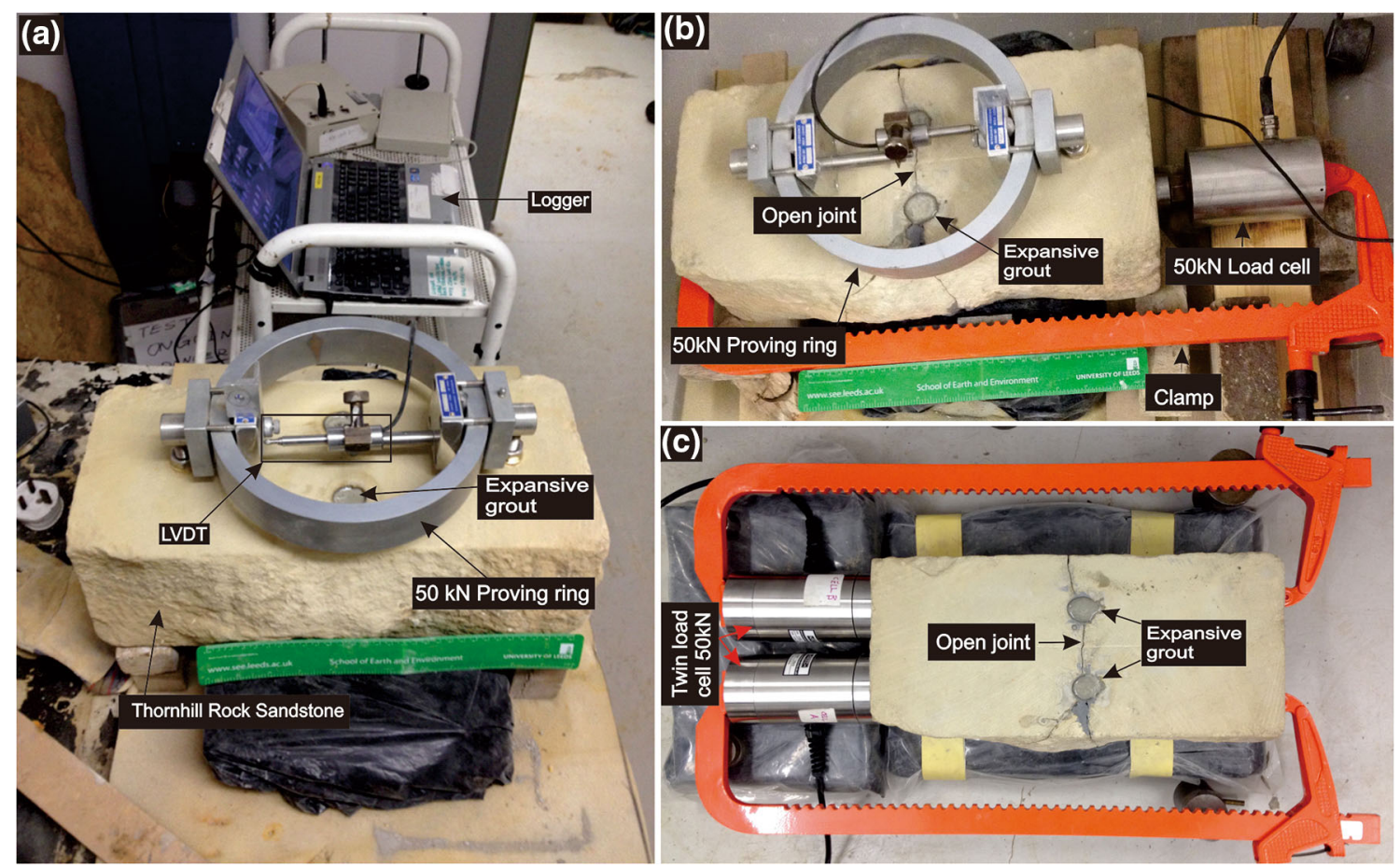

Fig. 9 a Experimental setup of the Phase i test on an ostensibly homogeneous Thornhill Rock Sandstone sample and setups of the Phase ii test on the same sample but containing the opened factures in the Phase i test using the Type 1 re-setup method (b) and the Type 2 re-setup method (c). Rule for scale is $350 \mathrm{~mm}$ in length

\subsubsection{Uniaxial compressive strength}

Five 25-mm-diameter core samples were prepared for the uniaxial compression test. In this test, a servo-controlled loading machine was used to apply load continuously with a constant loading rate of $1 \mathrm{MPa} / \mathrm{s}$ until sample failure.

\subsubsection{Point load strength}

Ten core-based samples ( $25 \mathrm{~mm}$ in diameter) with a length/diameter ratio ranging from 0.8 to 1.0 were prepared for the point load testing. The size correction factor was 0.75 during the strength calculation, and the mean point load strength values were calculated by deleting the highest and lowest values.

\subsubsection{Testing procedures}

Figure 9 presents the experimental setup on the intact Thornhill Rock Sandstone sample (without incipient joint). In the Phase i test, two symmetrical holes with a diameter of $25 \mathrm{~mm}$ were drilled through rock material vertically at a spacing of $30 \mathrm{~mm}$ (Fig. 9a). Spectrum plasticine was used to seal the bottoms of pre-drilled holes to prevent the expansive grout from leaking. A LVDT with a 50-kN PR was installed on the top of the sample. A measuring jug, syringe and soft drink bottle were used to measure Dexpan power and water to the suggested ratio $(3.3 \mathrm{~kg} / \mathrm{L})$. A metal stick was employed to mix the Dexpan power and water in a plastic bucket. A measuring jug and syringe were used to fill and measure the amount of chemical splitter involved in the pre-drilled holes. The metal stick was also used to agitate the expansive grout in the holes making sure no air was trapped in holes. A laptop was used to log the displacement of the LVDT during the test.

The ETF arising from the expansive grout was measured in the Phase ii test in which the sample used in the Phase $\mathrm{i}$ test but containing induced fractures was employed, as illustrated in Fig. 9b, c. In the test, the opened fractures were placed together but had no cohesion (no tensile strength). Spectrum plasticine was used to seal the hole edges and bottoms of holes. The ETF was measured several times, and an average value was calculated and used in the tensile strength calculation according to Eq. (1).

Two different setups were used in the Phase ii test. The first approach comprised a PR and a load cell, as shown in Fig. 9b. The cylindrical load cell $(150 \mathrm{~mm} \times 50 \mathrm{~mm})$ was installed at the base of the sample using a clamp, and other setup procedures were similar to those shown in Fig. 9a. The initial reading of the load cell was set to $0 \mathrm{kN}$. The amount and concentration of the expansive grout $(3.3 \mathrm{~kg} /$ 
L) was controlled to be the same as that in the Phase i test. For the second approach (Fig. 9c), two load cells with the same stiffness were employed to verify the validity of the ETF measured by the first approach (Fig. 9b).

\subsubsection{Sample failure patterns}

As can be seen in Fig. 10a, b, the induced fractures were irregular. Two fracture planes were induced on one side of the sample, while only one fracture plane was generated on the other side (Fig. 10c). The irregular failure pattern can be related to the inhomogeneity of the sample tested. Although an irregular failure plane was induced, the plane perpendicular to the direction of the ETF was treated as the failure plane under tension (Fig. 10d), and its projected area was used in the calculation of the tensile strength. A gap was observed at the base of the sample (see Fig. 10c), and the explanation for the gap is in Sect. 3.1. (It is due to the confinement of the sample at the top only, by the proving ring.)

\subsubsection{Test results}

Figure 11a shows the measured displacement of the LVDT against time in the Phase i test (see Fig. 9a). The Phase ii tests were conducted three times, and all forces measured using the PR and load cells are presented in Fig. 11b.

Two turning points (points $b$ and $c$ ) are observed in Fig. 11a. At the point $b$, the LVDT (initially under tension) started to measure displacement of the sample. At the point c, the LVDT started to compress which indicates the complete failure of the sample because sample hinges creating the gap at the bottom when it failed (as described in Sect. 3.1). Thus, the point $\mathrm{c}$ corresponds to the time $t_{2}$ described in the conceptual test model (Fig. 5).

As shown in Fig. $11 \mathrm{a}$, the time at the point $\mathrm{b}$ was $51514 \mathrm{~s}$ after test initiation and it was $58417 \mathrm{~s}$ at the point $\mathrm{c}$ when sample failed. Figure $11 \mathrm{~b}$ shows the measured forces in the Phase ii test (Type 1 re-setup method, Fig. 9b). Table 1 lists the parameters and forces measured at the point $\mathrm{c}$ in the Phase ii test. The $\mathrm{ETF}_{(58417 \mathrm{~s})}$ was calculated by adding up the forces measured by the PR and load cells, and an average ETF of $-33.4 \mathrm{kN}$ (see the last
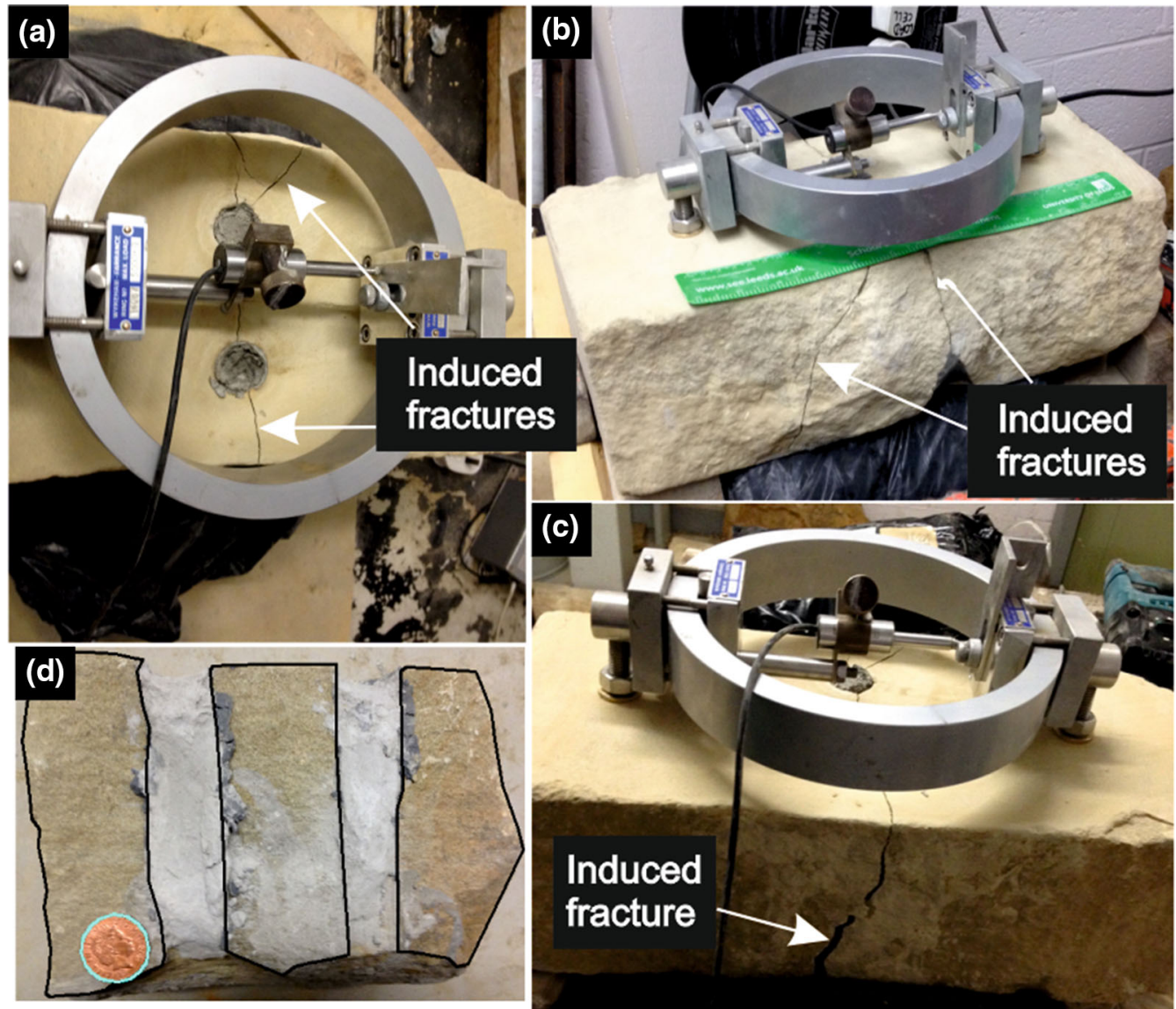

Fig. 10 Failure patterns of the Thornhill Rock Sandstone sample under tension in the Phase i test described in Fig. 9a. a Front view; b left view; c right view; and $\mathbf{d}$ one failure plane (enveloped areas) used for the tensile strength calculation 


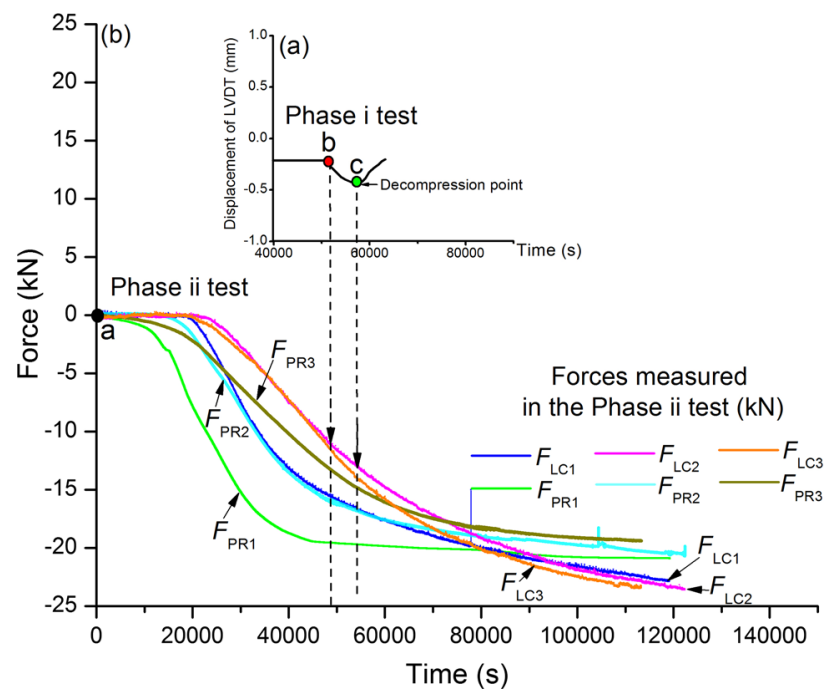

Fig. 11 a Displacement of LVDT versus time measured in the Phase i test on the intact Thornhill Rock Sandstone sample and $\mathbf{b}$ measured force against time in the Phase ii test using the Type 1 re-setup method, in which forces were measured three times

column in Table 1) was calculated. The area of the failure plane $\left(18,192 \mathrm{~mm}^{2}\right)$ was measured by AutoCAD. Thus, the tensile strength of the tested block-scale Thornhill Rock Sandstone sample was calculated according to Eq. (1), and it was $-1.8 \mathrm{MPa}$.

For comparison, Brazilian discs of Thornhill Rock Sandstone were prepared according to the ISRM standard. Average Brazilian tensile strength was obtained $(3.5 \pm 0.5 \mathrm{MPa})$, as shown in the last column in Table 2. It can be seen that magnitude of the tensile strength of blockscale sample measured in this test $(1.8 \mathrm{MPa})$ was approximately half of that obtained from Brazilian test $(3.5 \pm 0.5 \mathrm{MPa})$.
Figure 12 presents the measured forces versus time using the Type 2 re-setup method (using two load cells, Figs. 8b and 9c). Results (LVDT displacement versus time) in the Phase i test are also included. It can be seen that the ETF was $-33.9 \mathrm{kN}$ (the sum of -16.1 and $-17.8 \mathrm{kN}$ ) at the time of $58,417 \mathrm{~s}$, which was in the range $(-31.2$ to $-37.2 \mathrm{kN}$ ) of the ETF values obtained by the Type 1 resetup method (the 7th column in Table 1). It is also interesting to note that this value $(-33.9 \mathrm{kN})$ was very close to the average ETF $(-33.4 \mathrm{kN}$, see Table 1$)$. This gave some evidence that the ETF results obtained by the Type 1 re-setup test using the proving ring and load cell are acceptable.

\subsection{Tensile tests on Midgley Grit Sandstone with twin open cuts}

A Midgley Grit Sandstone (dimensions $100 \mathrm{~mm}$ (height) $\times 380 \mathrm{~mm}$ (length) $\times 170 \mathrm{~mm}$ (width) block was collected from the Blackhill Quarry, West Yorkshire, UK. The lithology was the same as those cylindrical samples tested by Shang et al. [32] in the laboratory for direct tension. The block sample was stored in the engineering geology laboratory at Leeds University prior to testing. Some physical and mechanical properties including water content (3.2\%), Schmidt hammer rebound hardness $(20.8 \pm 4.2)$, uniaxial compressive strength $(25 \pm 3.1 \mathrm{MPa})$ and point load strength $I_{\mathrm{S}(50)}$ $(1.4 \pm 0.3 \mathrm{MPa})$ were measured according to the ISRM standards. The test procedures are the same to those described in Sect. 4.1.

Table 1 Parameters and forces measured in the Phase ii test on the Thornhill Rock Sandstone sample (Hole diameter is $25 \mathrm{~mm}$ )

\begin{tabular}{lllllll}
\hline Time $(\mathrm{s})$ & Test number & Expansive grout volume $(\mathrm{ml})$ & Temperature $\left({ }^{\circ} \mathrm{C}\right)$ & $F_{\mathrm{PR}}(\mathrm{kN})$ & $F_{\mathrm{LC}}(\mathrm{kN})$ & $\mathrm{ETF}(\mathrm{kN})$ \\
\hline 58,417 & 1 & 65.6 & 23 & -19.8 & -17.4 & -37.2 \\
& 2 & 71 & 20 & -17.4 & -14.3 & -31.7 \\
& 3 & 72.6 & 19 & -15.8 & -15.4 & -31.2 \\
\hline
\end{tabular}

Table 2 Brazilian tensile strength of the Thornhill Rock Sandstone

\begin{tabular}{llllll}
\hline Sample & Diameter $(\mathrm{mm})$ & Length $(\mathrm{mm})$ & Maximum load $(\mathrm{kN})$ & Stress $(\mathrm{MPa})$ & Average stress $(\mathrm{MPa})$ \\
\hline 1 & 54.1 & 28 & 7.8 & 3.3 & $3.5 \pm 0.5$ \\
2 & 54.2 & 29 & 6.9 & 2.8 & \\
3 & 53.8 & 27.5 & 8.7 & 3.7 & \\
4 & 54.6 & 23 & 7.1 & 3.6 & \\
5 & 54.2 & 24 & 8.5 & 3.2 & \\
6 & 54.5 & 28.5 & 7.4 & 3.1 & \\
\hline
\end{tabular}




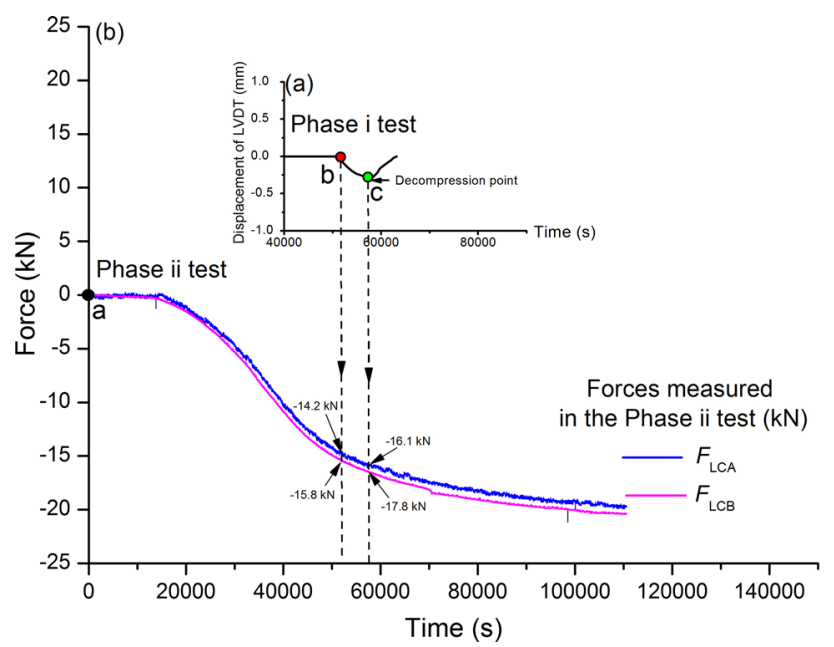

Fig. 12 a Displacement of LVDT versus time measured in the Phase i test on the intact Thornhill Rock Sandstone sample and b measured force versus time in the Phase ii test using the Type 2 re-setup method

\subsubsection{Testing procedures and sample failure modes}

The test comprised two phases: the Phase i test on the intact Midgley Grit Sandstone sample without incipient joints and the Phase ii test on the same sample but containing an induced fracture.

The test procedures are similar to those described in the tension test on the Thornhill Rock Sandstone sample in Sect. 4.1. The major difference of the setup to the previous test is that twin open cuts with an aperture of approximately $2 \mathrm{~mm}$ were produced using a diamond wheel saw from the edge of the block sample to the holes for chemical splitter, as shown in Fig. 13a, aiming to get a single failure plane. Figure $13 \mathrm{~b}$ presents the photograph at the completion of the Phase i test. A larger gap (see Fig. 13c) was created at the base of the sample. One induced fracture approximately perpendicular to the direction of ETF can be seen on the top of the sample (see Fig. 13d). The areas of the failure surfaces presented in Fig. 13e, f were measured by AutoCAD which were $8105 \mathrm{~mm}^{2}$ and $8596 \mathrm{~mm}^{2}$, respectively.

Again, two different re-setup methods (Fig. 14a, d, e and g) were employed in the Phase ii test to measure the force from the chemical splitter used. The procedures were the same as those described in Fig. 9b, c. The fracture induced in the Phase i test was re-opened again in the Phase ii test to an aperture of around $1.5 \mathrm{~mm}$, as shown in Fig. 14b, c, f and h (images were taken after $24 \mathrm{~h}$ ).

\subsubsection{Test results and tensile strength calculation}

Figure 15 shows the test results. The Phase i test curve demonstrated the time (20339 s) for the initiation of failure (at the point b) and the time (34724 s) for complete failure (at the point c, Fig. 15a). Figure 15b presents the force versus time measured in the Phase ii test. The parameters and forces measured in the Phase ii test are listed in Tables 3 and 4.

The average ETF value was calculated $(-16.6 \mathrm{kN}$, i.e. average of $\left(F_{\mathrm{LCA}}+F_{\mathrm{LCB}}=-13.84 \mathrm{kN}\right)$ and $\left(F_{\mathrm{PR} 1}+-\right.$ $\left.F_{\mathrm{LC} 1}=-19.36 \mathrm{kN}\right)$ ) at the time of $34,724 \mathrm{~s}$. The failed area between the two drill holes was $8351 \mathrm{~mm}^{2}$ (see Fig. 13e, f). Thus, the tensile strength of the Midgley Grit Sandstone sample tested was $2.0 \mathrm{MPa}$. The implied tensile strength of block-scale Midgley Grit Sandstone is less than the average value measured by Brazilian test (2.4 MPa), it also lies below the range of tested values (2.29-2.52 MPa). It is, however, worth to be noting that the strength (2.0 MPa) measured in this test lies between the strength range $(2.08 \pm 0.22)$ measured using the uniaxial tensile method on core-scale cylindrical samples [32].

\section{Tensile tests on a single incipient joint}

The results of the tests undertaken on the intact Thornhill Rock Sandstone block without incipient joints indicate that a somewhat smaller tensile strength was measured using the proposed method than standard methods. The strength of the tested block-scale Midgley Grit Sandstone with twin side cuts was, however, much closer to Brazilian and uniaxial tensile strength. Discussion of this point will be given in Sect. 6. In this section, tensile strength of blockscale incipient rock joints was measured using the new approach.

Midgley Grit Sandstone samples containing a single incipient rock joint were selected for testing (Fig. 16a, b). The samples were irregular in shape, but containing apparently persistent joint traces on the surfaces. It is evident that the two incipient joints retain some strength. The incipient joint 1 in block BHQ 7 inclined at about 40 degrees to ground, while the incipient joint 2 in the sample BHQ 5 was sub-vertical with respect to ground. Two holes with a diameter of $17 \mathrm{~mm}$ were drilled along the plane of incipient joint 2. The sample BHQ 5 was stained brown due to the presence of iron oxides. As can be seen in Fig. 16a, the stained bedding laminations were nearly perpendicular to the incipient joint plane.

\subsection{Setup and failure surfaces}

Figure $16 \mathrm{c}$, $d$ shows the experimental setups on the samples BHQ 7 and BHQ 5 which were similar to that used for the tests on intact rocks described in Sect. 4. During drilling, care needs to be taken to drill exactly along the joint planes as far as possible assuming that the joints are planar in shape and follow the traces as exposed at the surfaces. 


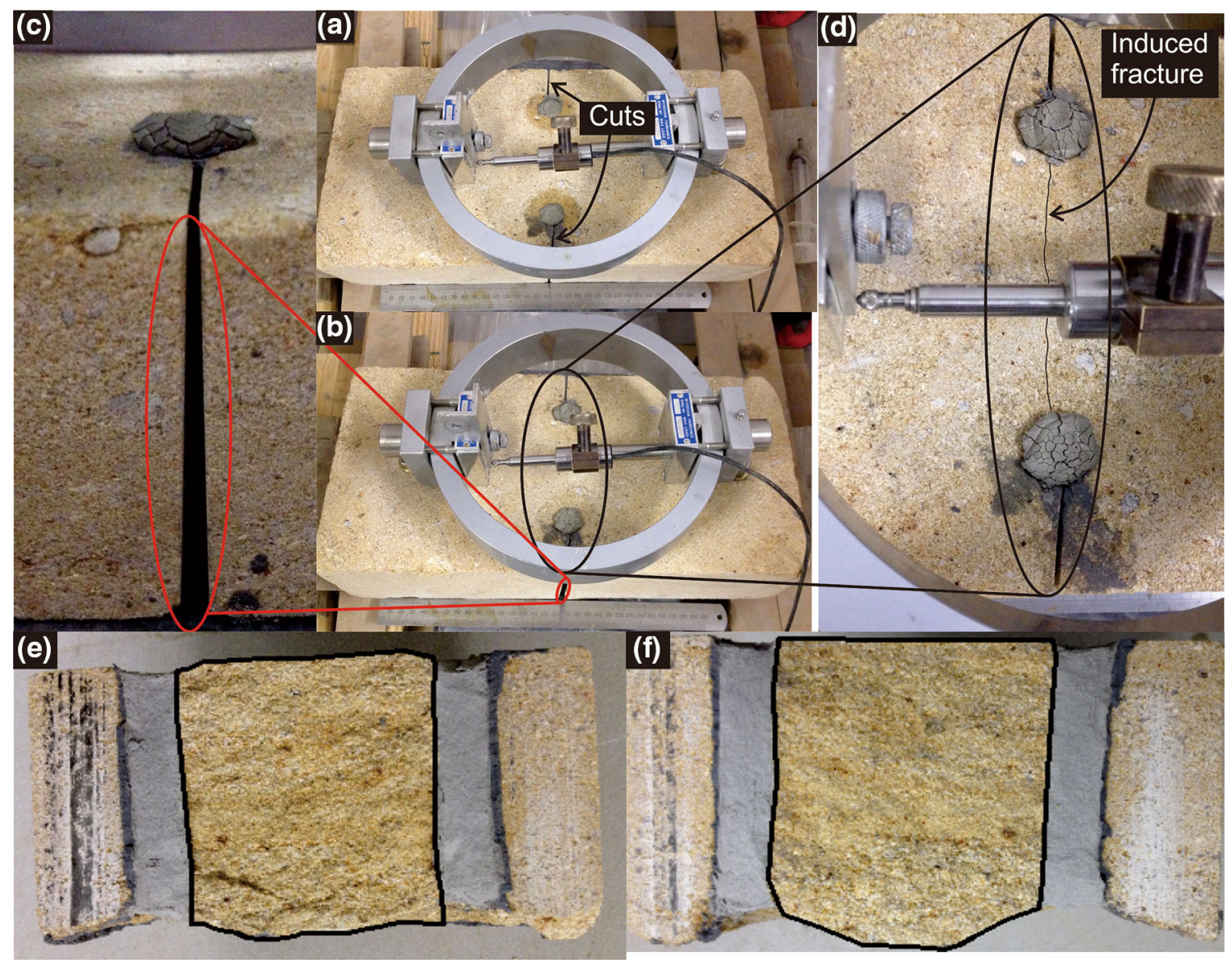

Fig. 13 a Experimental setup of the Phase i tension test on an ostensibly homogeneous Midgley Grit Sandstone with additional twin cuts. b The completion of test, a cut on one side of the sample (c) and an induced fracture on the top surface (d). Two opened failure surfaces are shown in (e) and (f). Note that black-enclosed areas are used for tensile strength calculation

Unlike the tests carried out on the intact Midgley Grit Sandstone, no cuts were made in the samples.

Failure surfaces of the incipient joints 1 and 2 are shown in Fig. 17. Following the approach used by Shang et al. [32], the joint surfaces were described using a two-colour classification: fresh/light-brown and black-mottled. The light-brown areas (enclosed by red lines) were interpreted as areas of rock bridges; the black-mottled areas were assumed persistent. It can be seen that both incipient joints 1 and 2 were not fully persistent in contrast to the continuity shown by the exposed traces on the block surfaces, but the non-persistent nature can only be viewed after splitting [33]. The persistent areas (black-mottled areas) have been highly weathered. If the areas enclosed by the red lines were assumed to be non-persistent (i.e. relatively fresh rock bridges), a persistence of $75 \%$ of the incipient joint 1 was calculated according to the definition of areal persistence [33]. An areal persistence of $63 \%$ was calculated for the incipient joint 2 (Fig. 17b).

\subsection{Tensile strength of the block-scale incipient rock joints}

Figures 18 and 19 present results of the tests on the incipient joints 1 and 2. Tables 5 and 6 list corresponding parameters and forces measured in the tests. As can be seen in Fig. 18a, it took around $49642 \mathrm{~s}$ for the incipient joint 1 to break (at the point c). An average ETF measured was - $15.6 \mathrm{kN}$ (see Tables 5 and 6). The irregular surface areas (whole area) of the incipient joint 1 (Fig. 17a) were traced and the projected areas were measured by AutoCAD and the value was $19,475 \mathrm{~mm}^{2}$. Thus, the tensile strength of incipient joint 1 was $-0.81 \mathrm{MPa}$. Similarly, it took $34876 \mathrm{~s}$ for the incipient joint 2 to break (at the point $\mathrm{c}$ in Fig. 18a). The average ETF at the corresponding time of $34876 \mathrm{~s}$ was $-8.0 \mathrm{kN}$ (see Tables 5 and 6 ). The measured surface area of the incipient joint 2 (see Fig. 17b) was $15,899 \mathrm{~mm}^{2}$. Thus, the tensile strength of the incipient joint 2 was $-0.51 \mathrm{MPa}$. 


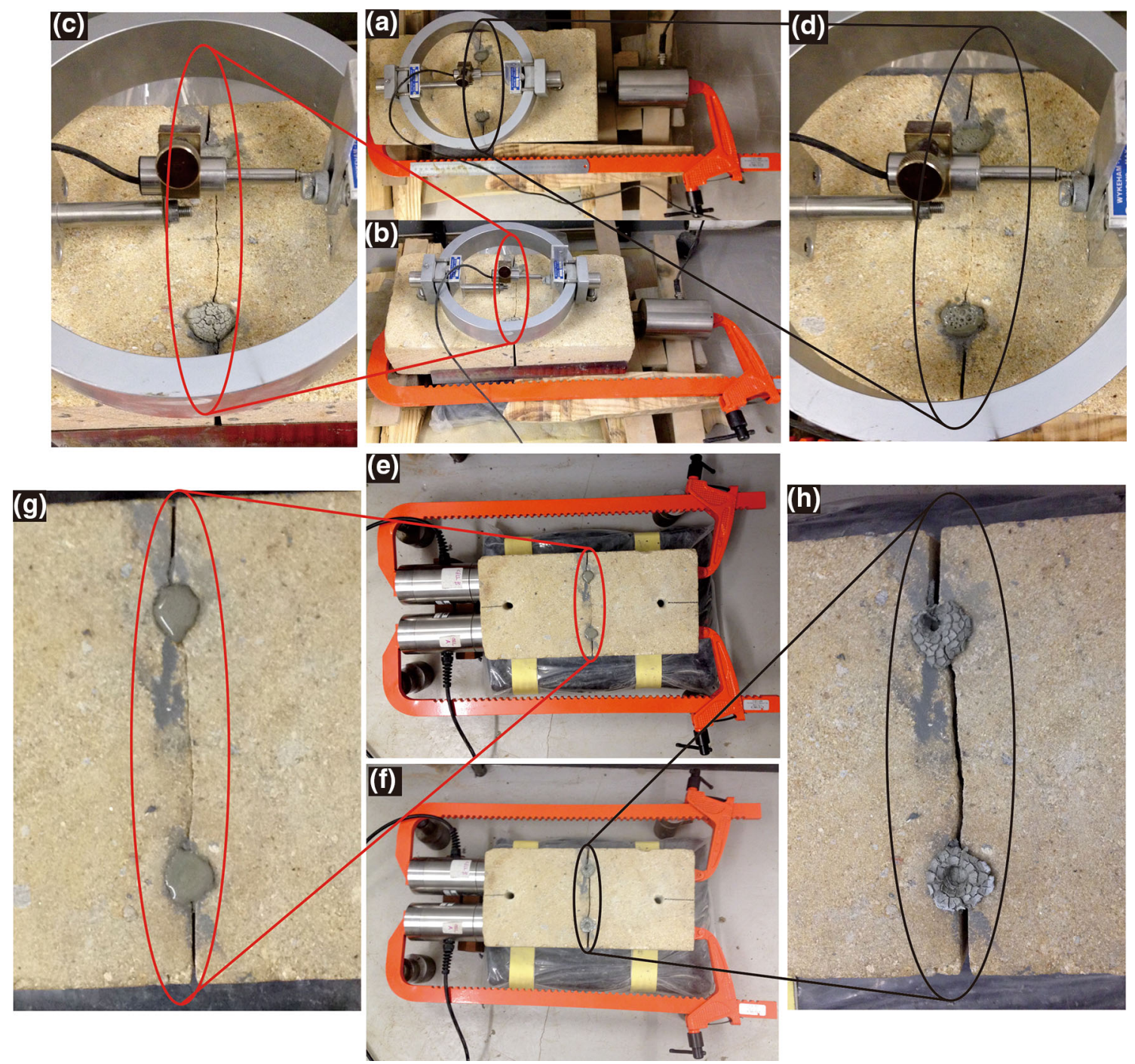

Fig. 14 Phase ii tests conducted on the Midgley Grit Sandstone sample containing a mechanical fracture (d and $\mathbf{g})$. The initiation (a) and completion (b) of the Type 1 re-setup tests. The initiation (e) and completion (f) of the Type 2 re-setup tests. The original induced fracture was re-opened (c) and (h)

\section{Discussion}

\subsection{ETF arising from the chemical splitter}

The tensile strength calculation relies on the assumption that the ETF measured in the Phase ii test represents the ETF at the same time in the Phase i test. Three main parameters including grout concentration, grout amount and room (rock) temperature will potentially affect the magnitude of the ETF from chemical splitter in the test. As the samples containing the fractures induced in the Phase $\mathrm{i}$ test were employed in the Phase ii test to measure ETF, the amounts of chemical splitter used in Phase $i$ and Phase ii tests were similar. All tests were conducted at the recommended grout concentration of $3.3 \mathrm{~kg} / \mathrm{L}$ and at room temperature $\left(20 \pm 2{ }^{\circ} \mathrm{C}\right.$ ). The ETF (normal to the failure plane) was measured using two different setup methods in the Phase ii test. A PR and a 50-kN load cell were employed in the Type 1 setup method (Fig. 8a), and twin load cells with the same stiffness were used in the Type 2 setup method (Fig. 8b). The ETF was calculated by adding up the readings of the PR and LC in the Type 1 method, and of twin load cells in the Type 2 method.

It was found that ETF measured by the Type 2 method was in broad agreement with values measured by the Type 1 method (see Figs. 11, 12, 15, 18 and 19). This indicates that the measured ETF gives a reasonable and acceptable result in the two different setup methods, so that averaging the forces measured by both methods is reasonable approach. [For some tests, however, there were some differences at the earlier stage of testing but similar ultimate ETF values at the end of each test run. For 


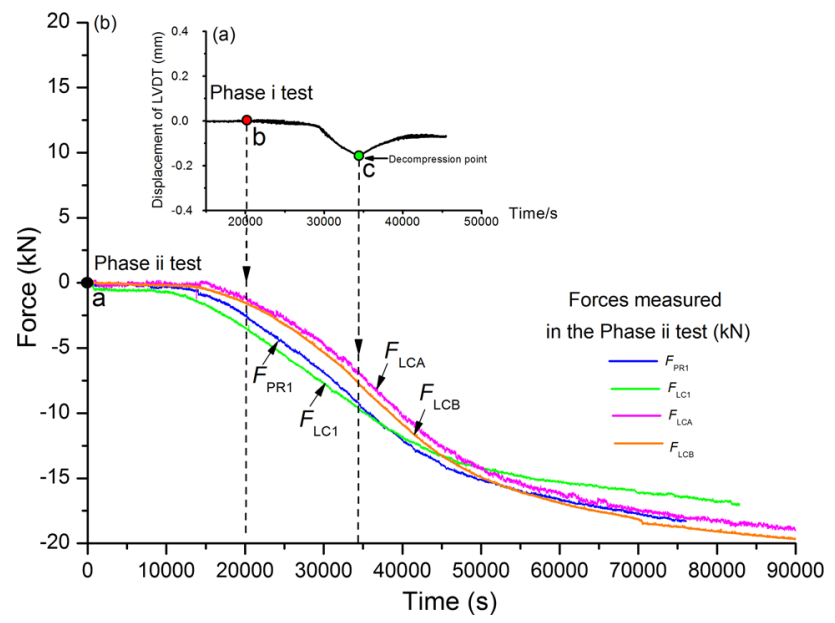

Fig. 15 a Displacement of LVDT versus time during the Phase i test on the Midgley Grit Sandstone sample and $\mathbf{b}$ force against time in the Phase ii test using the same sample but containing the previous opened fracture

example, in the curve labelled as $F_{\mathrm{PR} 1}$ in Fig. $11 \mathrm{~b}$, much larger force was measured before $50000 \mathrm{~s}$ compared with other test results. This is probably related to the slightly higher working temperature (see the fourth column in Table 1) during this test, which quickened the chemical reaction of splitter.]

Differences in ETF response between different test runs using the Type 1 method may also relate to the effect of the stiffness difference of the proving ring and load cells used in the Type 1 arrangement (Fig. 8a). Hence, for future experiments it is therefore suggested that ETF should be measured several times (at least twice) at the same room condition and that the load cell approaches (Type 2 method) are adopted.

Table 3 Parameters and forces measured by the Type 1 re-setup method in the Phase ii test on the Midgley Grit Sandstone sample (hole diameter is $17 \mathrm{~mm}$ )

\begin{tabular}{llllll}
\hline $\begin{array}{l}\text { Time } \\
(\mathrm{s})\end{array}$ & $\begin{array}{l}\text { Expansive } \\
\text { grout volume } \\
(\mathrm{ml})\end{array}$ & $\begin{array}{l}\text { Temperature } \\
\left({ }^{\circ} \mathrm{C}\right)\end{array}$ & $\begin{array}{l}F_{\mathrm{PR}} \\
(\mathrm{kN})\end{array}$ & $\begin{array}{l}F_{\mathrm{LC}} \\
(\mathrm{kN})\end{array}$ & $\begin{array}{l}\mathrm{ETF} \\
(\mathrm{kN})\end{array}$ \\
\hline 20,339 & 42.6 & 20 & -2.69 & -3.56 & -6.25 \\
34,724 & 42.6 & 20 & -9.57 & -9.79 & -19.36 \\
\hline
\end{tabular}

Table 4 Parameters and forces measured by the Type 2 re-setup method in the Phase ii test on the Midgley Grit Sandstone sample (Hole diameter is $17 \mathrm{~mm}$ )

\begin{tabular}{llllll}
\hline $\begin{array}{l}\text { Time } \\
(\mathrm{s})\end{array}$ & $\begin{array}{l}\text { Expansive } \\
\text { grout volume } \\
(\mathrm{ml})\end{array}$ & $\begin{array}{l}\text { Temperature } \\
\left({ }^{\circ} \mathrm{C}\right)\end{array}$ & $\begin{array}{l}F_{\mathrm{LCA}} \\
(\mathrm{kN})\end{array}$ & $\begin{array}{l}F_{\mathrm{LCB}} \\
(\mathrm{kN})\end{array}$ & $\begin{array}{l}\text { ETF } \\
(\mathrm{kN})\end{array}$ \\
\hline 20,339 & 43.5 & 20 & -1.72 & -2.01 & -3.73 \\
34,724 & 43.5 & 20 & -6.32 & -7.52 & -13.84 \\
\hline
\end{tabular}

\subsection{Sample scale}

The scale effect on the strength of rock and discontinuities has been investigated by many researchers [10, 26, 38, 41]. The common agreement about scale effect is that increase in strength values corresponds with the decrease in sample size. This phenomenon can be attributed to the heterogeneous nature of rock matrices. Rock material with a larger volume is able to contain more defects, and thus it is easier to break under external loading [35].

The failed rock surface areas of the large-scale block samples reported in this paper were about 5 times larger than those of the cylindrical samples with a diameter of $50 \mathrm{~mm}$ tested using uniaxial tension. It is interesting, however, to note that the measured tensile strength of the block-scale Midgley Grit Sandstone sample (2.0 MPa) was larger than the lowest value of measured tensile strength of the intact samples using the uniaxial tension method (1.86 MPa) [32]. In the test, two regular failure planes (Figs. 13e, f) were obtained at the end of test run. In contrast, failure planes were irregular in the block-scale test on the Thornhill Rock Sandstone sample. (Two induced fractures were produced on one side of the sample, and only one fracture was induced on the other side, Fig. 10.) The major difference in the test setup (two cuts were made in the intact Midgley Grit Sandstone sample, but not in the Thornhill Rock Sandstone block, see Fig. 13a) may give a possible explanation. The force acting the irregular plane is complex, and may have allowed progressive failure of the sample, which will affect tensile strength calculation. As reported by Kittitep and Numchok [21], failure patterns of sandstone samples under Brazilian tension were related to the average tensile strength. It is therefore suggested that intact samples with twin cuts (as shown in Fig. 13a) are preferred in the large-scale experiment, to avoid the development of irregular failure planes.

The tensile strength of the tested large-scale incipient joints 1 and 2 is $0.81 \mathrm{MPa}$ and $0.51 \mathrm{MPa}$, respectively. It is difficult to verify the validity of the two values, but a backcalculation of the tensile strength of the non-persistent areas may give some clue, following the approach adopted by Shang et al. [32]. For the tested incipient rock joints, the non-persistent areas (red envelopes in Fig. 17) were clearly not intact rock but have been stained to some degree. The enveloped areas on the incipient joint planes 1 and 2 were measured (4927 and $5914 \mathrm{~mm}^{2}$ ) approximately using AutoCAD. The calculated tensile strength of these two non-persistent areas was 1.8 and $1.3 \mathrm{MPa}$, which were smaller than the intact rock uniaxial tensile strength (2.08 MPa). This means that the slightly stained segments on the non-persistent areas of the failure surfaces have strength somewhat less than the intact rock strength. 

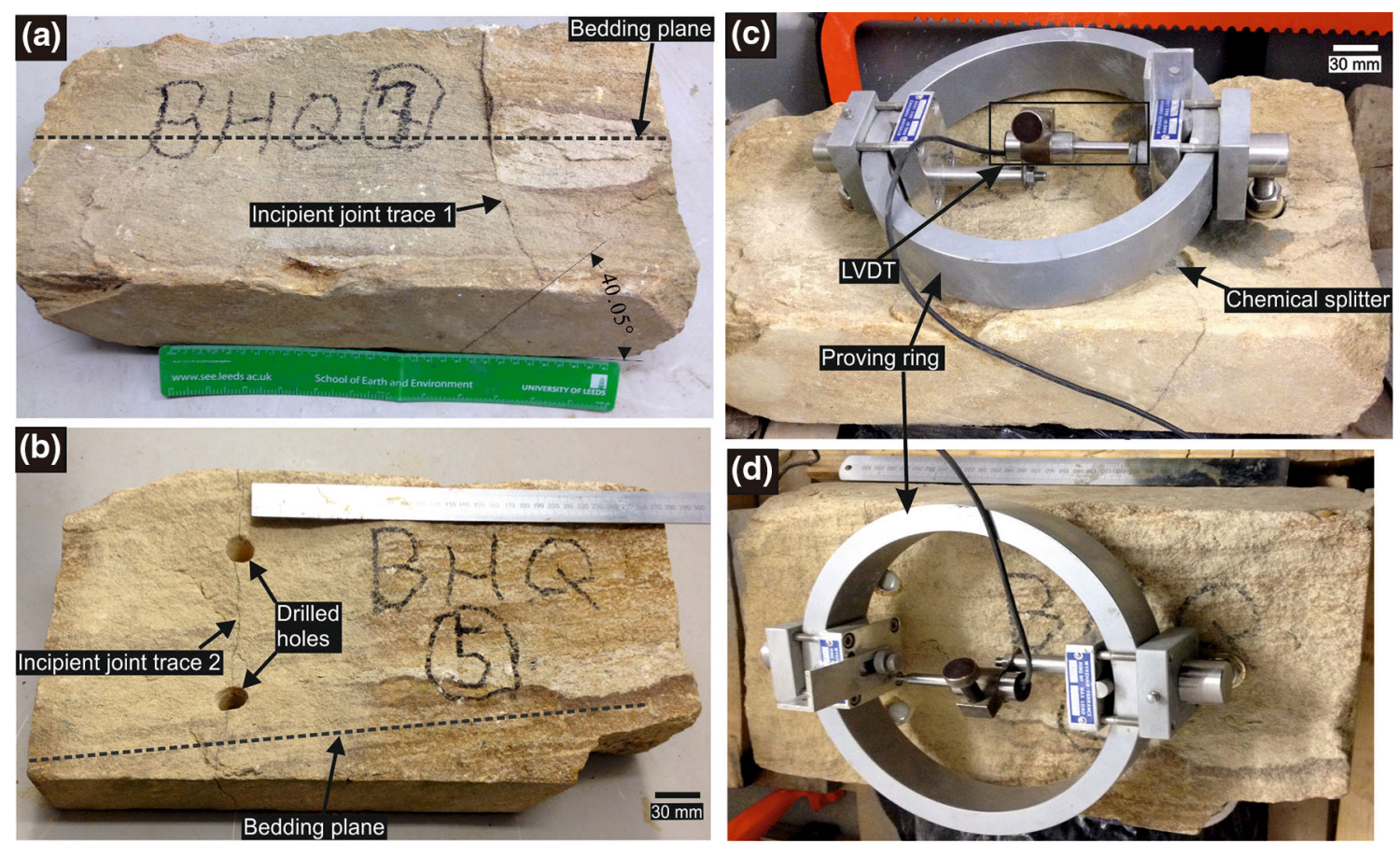

Fig. 16 a, b Midgley Grit Sandstone samples (BHQ 7 and BHQ 5) containing the incipient joint traces 1 and 2. c, d Experimental setup of the tension tests on the samples with incipient joints
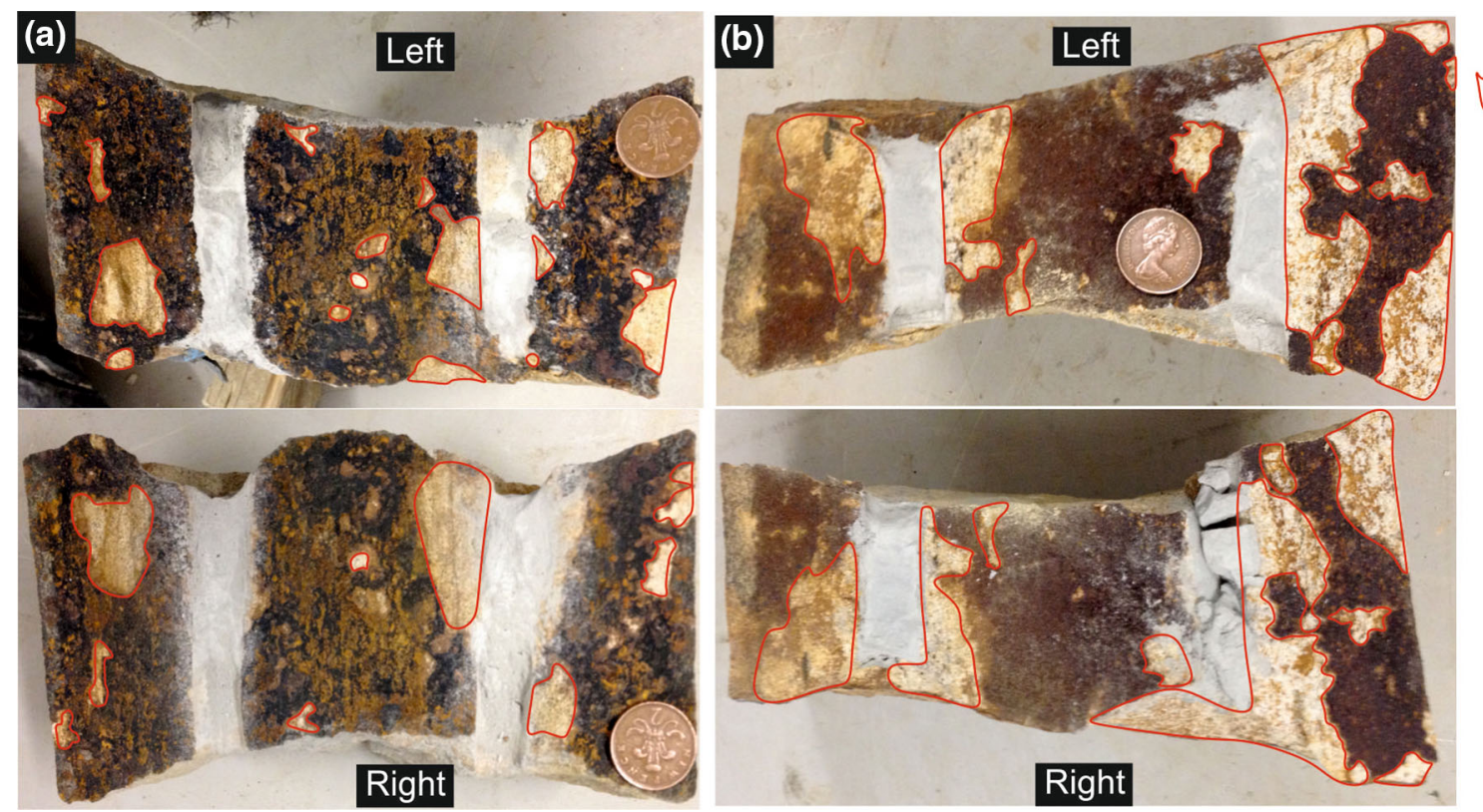

Fig. 17 Broken surfaces of the incipient rock joints after the tension tests. a Two opposite surfaces of the incipient joint 1 and $\mathbf{b}$ two opposite surfaces of the incipient joint 2

The above results are broadly similar to those conducted on smaller cylindrical samples of the same lithology containing incipient joints [32]. In that study, it was also shown that rock bridges (intact areas) of the incipient joints had somewhat smaller strength than the intact rock.

\subsection{Stress concentration during the tension test}

Laboratory methods including direct and indirect tensile tests were employed to measure the tensile strength of rock materials $[14,22,23,25]$. In those tests, uniformly distributed stresses along failure planes are the basis of valid 


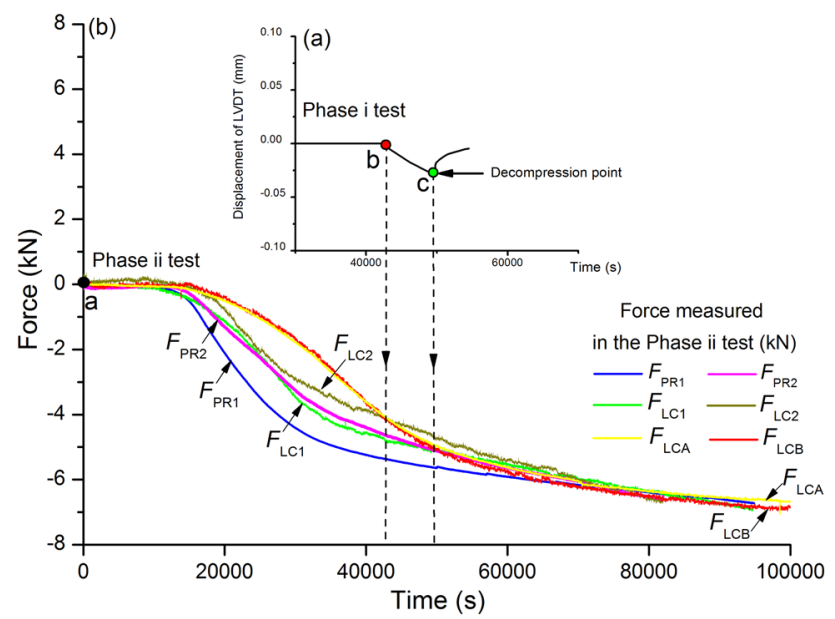

Fig. 18 a Displacement of LVDT versus time during the Phase i test on the incipient joint 1 within the BHQ 7 and $\mathbf{b}$ force versus time in the Phase ii tests using the same sample but containing the previous opened fracture

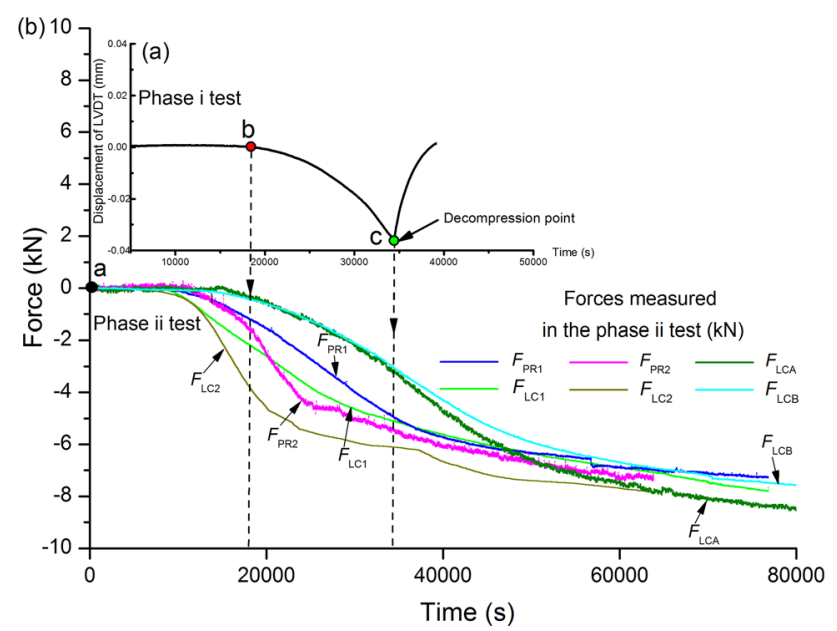

Fig. 19 a Displacement of LVDT against time during the Phase i test on the incipient joint 2 within the BHQ 5 and $\mathbf{b}$ force versus time in the Phase ii test using the same sample but containing the previous opened fracture results. Efforts have been made to reduce the anomalous concentrated stresses within rocks during testing [15, 40].

For large-block tests reported here, stress may concentrate around the edges of the chemical splitter-filled holes [31]. The anomalous concentrated stress distributions in the block tests give an explanation to the somewhat smaller laboratory test results compared with those measured by the Brazilian test. Another consideration is that for tension tests carried out on incipient rock joints, stress would also concentrate around rock bridge tips. This may actually represent the field situation or in situ stress condition because of the intrinsic nature of incipient rock joints.

\subsection{Effects of loading rate and water on the strength}

Strength of rock materials varies with the loading rate $[21,37]$. Tensile strength of rock materials can also vary with test methods as well as loading rates, leading to uncertainty [6]. In this study, chemical splitter (a kind of expansive grout made from mixturing Dexpan power and pure water with a recommended ratio of $3.3 \mathrm{~kg} / \mathrm{L}$ ) was used to apply expansive tensile force in the large-block tests. As can be anticipated that the influential factors including working temperature, concentration and amount of chemical splitter evolved in each test will influence the pressurization rate of chemical splitter. From the test results, it took several hours for chemical splitter to break intact rock as well as incipient rock joints. Obviously, that is much longer than conventional tensile tests (up to several minutes), i.e. a very small loading rate was applied on the rock materials in the test. It is suspected that the smaller strength obtained may be attributed to the smaller loading rate, as suggested by Mellor and Hawkes [28] who report that tensile strength of rock will decrease with decreasing loading rate. In addition, water in the chemical splitter can

Table 5 Parameters and forces measured by the Type 1 re-setup method in the Phase ii tests on incipient joints (hole diameter is $17 \mathrm{~mm}$ )

\begin{tabular}{|c|c|c|c|c|c|c|}
\hline Sample & Time (s) & Expansive grout volume (ml) & Temperature $\left({ }^{\circ} \mathrm{C}\right)$ & $F_{\mathrm{PR}}(\mathrm{kN})$ & $F_{\mathrm{LC}}(\mathrm{kN})$ & ETF $(\mathrm{kN})$ \\
\hline \multirow[t]{4}{*}{ Incipient joint 1} & 42,884 & 35.6 & 19 & -5.4 & -4.8 & -10.2 \\
\hline & & 31 & 20 & -4.6 & -4.1 & -8.7 \\
\hline & 49,642 & 35.6 & 19 & -5.4 & -5.1 & -10.5 \\
\hline & & 31 & 20 & -5.1 & -5.0 & -9.6 \\
\hline \multirow[t]{2}{*}{ Incipient joint 2} & 19,797 & 28.5 & 20 & -2.6 & -1.5 & -4.1 \\
\hline & 34,876 & 28.5 & 20 & -4.7 & -5.0 & -9.7 \\
\hline
\end{tabular}

For the tests on the incipient joint 1 , the average ETF was $-15.6 \mathrm{kN}\left(-(10.5+9.6+9.7) / 3 * \sin 40.05^{\circ}\right)$, while it was $-8.0 \mathrm{kN}$ $(-(9.7+6.39) / 2))$ for the tests on the incipient joint 2 . The ETF values $(-9.7$ and $-6.39 \mathrm{kN})$ measured by the Type 2 method are shown in Table 6 
Table 6 Parameters and forces measured by the Type 2 re-setup method in the Phase ii tests on incipient joints (hole diameter is $17 \mathrm{~mm}$ )

\begin{tabular}{lllllll}
\hline Sample & Time $(\mathrm{s})$ & Expansive grout volume $(\mathrm{ml})$ & Temperature $\left({ }^{\circ} \mathrm{C}\right)$ & $F_{\mathrm{LCA}}(\mathrm{kN})$ & $F_{\mathrm{LCB}}(\mathrm{kN})$ & $\mathrm{ETF}(\mathrm{kN})$ \\
\hline Incipient joint 1 & 42,884 & 35.6 & 20 & -4.02 & -4.03 & -8.05 \\
& 49,642 & 35.6 & 20 & -4.82 & -4.88 \\
Incipient joint 2 & 19,797 & 28.5 & 21 & -0.43 & -0.43 & -0.70 \\
& 34,876 & 28.5 & 21 & -2.85 & -3.54 \\
\hline
\end{tabular}

infiltrate and diffuse into the rock matrix in the test, which in turn may reduce the rock strength [28].

\subsection{Implications for rock mass classification}

ISRM standard defines discontinuities have very low or zero tensile strength [17]. Classic rock mass classification schemes such as Q system, RMR and RQD are defined on the basis of this engineering assumption which means that they all fail to resolve the issue of incipiency of discontinuities as well as varying degrees of tensile strength [34]. It would be beneficial if incipient discontinuities can be differentiated in terms of relative tensile strength in the rock mass classifications [32]. The practical methodology reported in this paper allow researchers and practitioners to estimate the in situ tensile strength of incipient rock discontinuities, thus providing a more scientific guidance for rock mass classification and engineering design. For $\mathrm{Q}$ system and RMR, an additional parameter reflecting the relative tensile strength of discontinuities is suggested to be included in their rock mass evaluation processes. Incipient rock joints with high relative tensile strength should not be counted when calculating the value of RQD.

\section{Summary and conclusion}

A practical testing methodology for quantifying the tensile strength of large-scale incipient rock joints was developed in this paper. In the test, a chemical splitter was used to generate tensile forces normal to incipient joint planes in large block samples. Each test comprises two phases: Phase $i$ test and Phase ii test. The time from injection of splitter to failure was measured in the Phase $i$ test; the expansive tensile force (ETF) arising from the chemical splitter was measured in the Phase ii test using the same sample previously broken in the Phase $i$ test. The magnitude of ETF (measured in the Phase ii test) at the time of sample failure (measured in the Phase $\mathrm{i}$ test) was employed to calculate the tensile strength of the plane through chemical splitterfilled holes. Preliminary tensile tests were firstly performed on large-scale ostensibly homogeneous Thornhill Rock Sandstone and Midgley Grit Sandstone samples to establish the methodology. Tensile strength of large-scale incipient joints was then measured using this new approach.

Tests on ostensibly homogeneous Thornhill Rock Sandstone gave a somewhat smaller tensile strength compared with those obtained by Brazilian and uniaxial tensile tests. Irregular failure planes generated due to inhomogeneity, stress concentration and relatively low loading rate may be responsible for these smaller tensile strengths. Other large-block tests on Midgley Grit Sandstone samples with a slightly modified method (i.e. additional twin cuts to guide the fracture process) gave a tensile strength (2.0 MPa), which lies within the range of strengths $(2.08 \pm 0.22)$ measured from uniaxial tension tests. Here, a planar failure was generated exactly through the drilled holes. In further tests on large-scale incipient rock joints, failure was induced through pre-existing incipient joint traces. Tensile strength of the large-scale incipient rock joints tested was close to that based on the core-scale uniaxial tension tests on incipient joints in the same lithology. Additional studies are needed to verify the scale effects on tensile strength of incipient rock discontinuities.

Open Access This article is distributed under the terms of the Creative Commons Attribution 4.0 International License (http://creative commons.org/licenses/by/4.0/), which permits unrestricted use, distribution, and reproduction in any medium, provided you give appropriate credit to the original author(s) and the source, provide a link to the Creative Commons license, and indicate if changes were made.

\section{References}

1. Bahaaddini M, Sharrock G, Hebblewhite BK (2013) Numerical investigation of the effect of joint geometrical parameters on the mechanical properties of a non-persistent jointed rock mass under uniaxial compression. Comput Geotech 49:206-225

2. Bandis SC, Lumsden AC, Barton N (1981) Experimental studies of scale effects on the shear behaviour of rock joints. Int $\mathrm{J}$ Rock Mech Min Sci Geomech Abstr 18:1-21

3. Bonilla-Sierra V, Scholtes L, Donze FV, Elmouttie MK (2015) Rock slope stability analysis using photogrammetric data and DFN-DEM modelling. Acta Geotech 10(4):497-511

4. Borrelli L, Greco R, Gulla G (2007) Weathering grade of rock masses as a predisposing factor to slope instabilities: reconnaissance and control procedures. Geomorphology 87:158-175

5. Brian DC, Greg MS (2016) Rockfall triggering by cylic thermal stressing of exfoliation fractures. Nat Geosci 9:395-400 
6. Chang C, Jo Y (2015) Heterogeneous in situ stress magnitudes due to the presence of weak natural discontinuities in granitic rocks. Tectonophysics 664:83-97

7. Cravero M, Labichino G (2004) Analysis of the flexural failure of an overhanging rock slab. Int $J$ Rock Mech Min Sci 41(S1):605-610

8. Gehle C, Kutter HK (2003) Breakage and shear behaviour of intermittent rock joints. Int J Rock Mech Min Sci 30(40):687-700

9. Ghazvinian A, Nikudel MR, Sarfarazi V (2007) Effect of rock bridge continuity and area on shear behaviour of joints. In: 11th Congress of the international society for rock mechanics, 247-250

10. Gholamreza K, Rafiei B, Abdilor Y (2015) An experimental investigation of the Brazilian tensile strength and failure patterns of laminated sandstones. Rock Mech Rock Eng 48:843-852

11. Goudie AS (2016) Quantification of rock control in geomorphology. Earth-Sci Rev 159:374-387

12. Hencher SR (2014) Characterizing discontinuities in naturally fractured outcrop analogues and rock core: the need to consider fracture development over geological time. Advances in the study of fractured reservoirs. Geol Soc Lond Spec Publ 374:113-123

13. Hencher SR (1984) Three direct shear tests on volcanic rock joints. Geotechnical Control Office Information Notes, IN 15/84. Hong Kong Governments, p33 (unpublished)

14. Hobbs DW (1965) An assessment of a technique for determining the tensile strength of rock. Br J Appl Phys 16:259-268

15. Hoek E (1964) Fracture of anisotropic rock. J South Afr Inst Min Metall 64:501-518

16. Huynh MP, Laefer DF (2009) Expansive cements and soundless chemical demolition agents: state of technology review. In: 11th conference on science and technology, Ho Chi Minh City, Vietnam

17. ISRM (1978) Suggested methods for the quantitative description of discontinuities in rock masses. Int $\mathrm{J}$ Rock Mech Min Sci $15: 319-368$

18. ISRM (2015) The ISRM suggested method for rock characterization, testing and monitoring: 2007-2014. Springer. pp 292

19. Jennings JE (1970) A mathematical theory for the calculation of the stability of slopes in open cast mines: Planning Open Pit Mines. In: Proceedings of the symposium on the theoretical background to the planning of open pit mines with special reference to slope stability, Johannesburg, 87-102

20. Kalenchuk KS, Diederichs MS, Mckinnon S (2006) Characterizing block geometry in jointed rock masses. Int $\mathrm{J}$ Rock Mech Min Sci 43(8): 1212-1225

21. Kittitep F, Numchok K (2010) Influence of loading rate on deformability and compressive strength of three Thai sandstones. Geotech Geol Eng 28:707-715

22. Li HB, Li JC, Bo L, Li JR, Li SQ, Xia X (2013) Direct tension test for rock material under different strain rates at quasi-static loads. Rock Mech Rock Eng 46:1247-1254

23. Liao JJ, Yang MT, Hsieh HY (1997) Direct tensile behaviour of a transversely isotropic rock. Int $\mathrm{J}$ Rock Mech Min Sci 34(5):837-849

24. Longoni L, Arosio D, Scaioni M, Papini M, Zanzi L, Roncella R, Brambilla D (2012) Surface and subsurface non-invasive investigations to improve the characterization of a fractured rock mass. J Geophys Eng 9:461-472
25. Luong MP (1988) Direct tensile and direct shear strengths of Fontainebleau sandstone: key questions in rock mechanics. Balkema, Rotterdam

26. Manouchehr S, Lohrasb F, Ahmad F, Sareh G, Abolfazl M, Ashar R (2015) Shear strength of discontinuities in sedimentary rock masses based on direct shear tests. Int J Rock Mech Min Sci 75:119-131

27. Mauldon M (1994) Intersection Probabilities of impersistent joints. Int J Rock Mech Min Sci 31(2):107-115

28. Mellor M, Hawkes I (1970) Uniaxial testing in rock mechanics laboratories. Eng Geol 4(3):179-285

29. Paolo P, Alberto A, Elia R (2016) 3D stress-strain analysis of a failed limestone wedge influenced by an intact rock bridge. Rock Mech Rock Eng 49:3223-3242

30. Quinones J, Arzua J, Alejano LR, Garcia-Bastante F, Mas Ivars D, Walron G (2017) Analysis of size effects on the geomechanical parameters of intact granite samples under unconfined conditions. Acta Geotech. https://doi.org/10.1007/s11440-0170531-7

31. Shang J (2016) Persistence and tensile strength of incipient rock discontinuities. $\mathrm{PhD}$ thesis, the University of Leeds, Leeds, United Kingdom, p 248

32. Shang J, Hencher SR, West LJ (2016) Tensile strength of geological discontinuities including bedding, rock joints and mineral veins. Rock Mech Rock Eng 49(11):4213-4225

33. Shang J, Hencher SR, West LJ, Handley K (2017) Forensic excavation of rock masses: a technique to investigate discontinuity persistence. Rock Mech Rock Eng 50(11):2911-2928

34. Shang J, Duan K, Gui Y, Handley K, Zhao Z (2017) Numerical investigation of the direct tensile behaviour of laminated and transversely isotropic rocks containing incipient bedding planes with different strengths. Comput Geotech. https://doi.org/10. 1016/j.compgeo.2017.11.007

35. Sheshde EA, Cheshomi A (2015) New method for estimating unconfined compressive strength (UCS) using small rock samples. J Pet Sci Eng 133:367-375

36. Stimpson B (1978) Failure of slopes containing discontinuous planar joints. In: Proceedings of the 19th US symposium on rock mechanics, Stateline, Nevada, 296-302

37. Sopon W, Chaowarin W, Kittitep F (2015) Effects of loading rate and temperature on tensile strength an deformation of rock salt. Int J Rock Mech Min Sci 73:10-14

38. Thuro K, Plinniinger RJ, Zah S, Schutz S (2001) Scale effects in rock strength properties. Part 1: unconfined compressive test and Brazilian test: Rock Mechanics-a Challenge for Society, Sarkka \& Eloranta

39. Wieczorek GF, Jager S (1996) Triggering mechanisms and depositional rates of postglacial slope-movement processes in the Yosemite Valley, California. Geomorphology 15:17-31

40. Wuerker RG (1955) Measuring the tensile strength of rock. Min Eng 7(2):157-168

41. Zhang Q, Zhu H, Zhang L, Ding X (2011) Study of scale effect on intact rock strength using particle flow modelling. Int J Rock Mech Min Sci 48:1320-1328

42. Zimmerman RW, Chen DW, Cook NGW (1992) The effect of contact area on the permeability of fractures. J Hydrol 139:79-96 